\title{
Impact of Flashover Fire Conditions on Exposed Energized Electrical Cords/Cables
}

\author{
Craig Weinschenk (D) and Daniel Madrzykowski, Underwriters Laboratories, \\ 6200 Old Dobbin Lane, Columbia, MD 2105, USA \\ Paul Courtney, UL LLC, 333 Pfingsten Rd, Northbrook, IL 60062, USA
}

Received: 5 March 2019/Accepted: 2 October 2019

\begin{abstract}
There has been prior research exploring the exposure of common electrical cords and cables to fire, but that has traditionally been at the lab scale and under near steady-state exposures. The goal of these experiments was to expose six types of cords and cables in a room-scale compartment with a fuel load sufficient to drive the compartment through flashover. The basic test design was to expose the cords and cables on the floor of a compartment to a growing fire to determine the conditions under which the cord/cable would trip the circuit protection device. All of the cords were energized and installed on a non-combustible surface. The six cables and cords were protected by three different circuit protection devices which were remote from the thermal exposure. This configuration resulted in 18 exposures per experiment. The room fires experiments consisted of three replicate fires with two sofas as the main fuel source, two replicate fires with one sofa as the main fuel source and one fire with two sofas and vinyl-covered MDF paneling on three walls in the room. Each fuel package was sufficient to support flashover conditions in the room. The average peak heat release rate of the sofa fueled compartment fires with gypsum board ceiling and walls prior to suppression was $6.8 \mathrm{MW}$. The addition of vinyl covered MDF wall paneling on three of the compartment walls increased the pre-suppression peak heat release rate to $12 \mathrm{MW}$. In each experiment during post flashover exposure, the insulation on the cords and cables ignited and burned through, exposing bare wire. During this period, the circuits faulted. Assessments of both the thermal exposure and physical damage to the cords did not reveal any correlation between the thermal exposure, cord/cable damage, and trip type.
\end{abstract}

Keywords: Fire investigation, Electrical cords, Flashover exposure, Electrical cable

\section{Introduction}

According to NFPA 921, Guide for Fire and Explosion Investigation, there are four types of analysis that may be conducted to determine the area of origin of a fire: witness information, fire patterns, arc mapping, and fire dynamics [12]. In 2014, the Fire and Arson Investigation Technology Working Group Operational

\footnotetext{
* Correspondence should be addressed to: Craig Weinschenk, E-mail: craig.weinschenk@ul.org
} 
Requirements issued a set of operational requirements that included the characterization of electrical system response to fire as a research need [13].

These two documents motivate the current study. Fire investigators often find the remains of power cords that have been exposed to fire. The technical panel members agreed that there are two topics of interest: the thermal exposure of the cord prior to circuit trip, and the arc damage to cords.

As defined by NFPA 921, an arc fault involves a high-temperature, luminous electric discharge across a gap or through a medium such as charred insulation [12]. More specifically, arcing will occur between conductive surfaces once the insulation carbonizes, as carbon is a narrow bandgap semiconductor and can facilitate initiation of an arcing condition. Further, fire is electrically conductive and has the potential to short circuit electrified surfaces.

Béland developed several articles on the topic of arcing in the early 1980s [2-4]. Béland states that when energized electric wiring, such as power cords, from fixtures or appliances, or extension cords, were exposed to a fire environment, arcing was likely to occur due to the thermal degradation of the cord's insulation. One of the articles provided a few rough estimates of time to arcing. For a fire "well in progress" the time to arcing of the cord would be approximately $1 \mathrm{~min}$ for extension cords, $3 \mathrm{~min}$ for plastic sheathed cables, $5 \mathrm{~min}$ for a braided non-metallic sheathed cable and around $10 \mathrm{~min}$ for cords in metallic conduit [4].

Safety Engineering Laboratories, Inc. conducted a bench-scale study which exposed energized two conductor power cords, the type used for televisions and electronic appliances, to an electric radiant heat source with a flux of $40 \mathrm{~kW} / \mathrm{m}^{2}$ [8] with an exposure duration that did not exceed $15 \mathrm{~min}$. Damage to the copper cords ranged from localized fusing to severed cords. The energized cords did not always leave evidence of electrical arcs after the radiant thermal exposure, nor did the circuit breaker trip in every experiment. However, energized cords that were in contact with combustible surfaces or that were ignited by the radiant exposure, always provided evidence of electrical faults. Further the study did not find any correlations between the arc damage and the fire exposure, the type and construction of the insulating material, and magnitude or duration of the fault current. The time to the electrical fault occurred between approximately $4 \mathrm{~min}$ and $7 \mathrm{~min}$. Additional cords were exposed to an open flame. In these cases, the electrical faults occurred in $3 \mathrm{~min}$ or less.

Benfer and Gottuk conducted a series of experiments examining electrical receptacle fires for a U.S. Department of Justice project [5]. Part of their work included the exposure of 6 SPT cords connected to electrical receptacles for 3 compartment fire experiments in a compartment that was $3.7 \mathrm{~m}$ by $3.7 \mathrm{~m}$. The fire sizes approximately ranged between $1 \mathrm{MW}$ and $4 \mathrm{MW}$. Benfer and Gottuk found that all of the energized receptacles that had extension cords plugged in had tripped [5]. There was also evidence of arcing found on both the ground and neutral wires as well as severing of some to all of the strands of the cords.

Novak conducted an extensive study of NM-B 14-2 cables. The cable test samples had a $102 \mathrm{~mm}$ long section that was exposed to a nearly uniform heat flux. Energized and non-energized cables were exposed to heat fluxes ranging from 
$20 \mathrm{~kW} / \mathrm{m}^{2}$ to $55 \mathrm{~kW} / \mathrm{m}^{2}$. The source of the heat flux was an electric heater element from a cone calorimeter. Novak found that ignitions of the cable insulation generally occurred between $50 \mathrm{~kW} / \mathrm{m}^{2}$ and $55 \mathrm{~kW} / \mathrm{m}^{2}$, minimum heat flux to cause a faulted circuit was $22 \mathrm{~kW} / \mathrm{m}^{2}$, and the time-to-failure of the cables was related to the heat flux exposure $[14,15]$.

Many other studies have been conducted where NM type solid core electrical cables were installed on the ceilings and walls of compartments and exposed to fire environments. These experiments have focused more on the location of the damage to the cable for purposes of examining arc mapping, as opposed to examining the thermal conditions that generated the damage. Babrauskas recently published his literature review of arc mapping which includes references to this body of work [1].

Another consideration was the type of circuit protection that should be used in the fire experiments. There are three basic types of circuit protection in North America: (1) molded-case circuit breaker (MCCB), (2) ground-fault circuit interrupter (GFCI), and (3) arc-fault circuit interrupter (AFCI). Each action or purpose of each type of circuit protection is provided by the National Electrical Code [11] and is briefly described below.

The molded-case circuit breaker (MCCB) is a device designed to open and close a circuit by non-automatic means and to open the circuit automatically on a predetermined over-current without damage to itself when properly applied within its rating. The typical mechanism is a bi-metallic strip (thermal) but can also include an electro-magnetic switch; either method can trip the MCCB.

The GFCI is designed to de-energize a circuit when the supplied and returned current differ by more than $5 \mathrm{~mA} \pm 1 \mathrm{~mA}$ for a Class A device. The differential current is assumed to be returning by some other pathway, which may be due to a ground fault condition. A ground fault is defined as "an unintentional, electrically conductive connection between an ungrounded conductor of an electrical circuit and the normally non-current-carrying conductors, metallic enclosures, metallic raceways, metallic equipment, or earth [11]." Note, a GFCI may also have ther$\mathrm{mal} /$ magnetic protection built in.

The AFCI is intended to provide protection from the effects of arc faults while also providing conventional circuit protection. The AFCI monitors current waveforms and de-energizes the circuit when a waveform characteristic of an arc fault is detected. Through not required, AFCI devices can also provide over-current protection, over/under voltage protection, and ground-fault circuit interruption.

After reviewing the existing information and the technical panel input, a set of experiments was designed to expose different types of energized electrical cords and cables to a developing room fire exposure. All of the cords and cables would be positioned on the floor and arranged in a manner to receive a similar thermal exposure. The technical panel identified five types of cords and one type of cable commonly used in North American homes. All of the cords would be energized and they would be installed on a non-combustible surface. Non-metallic sheathed cables (i.e. Romex), typically found in residential electrical branch circuits, were included to provide a link to previous research. Note, the exposure of the non- 
metallic sheathed cables on the floor is not representative of how it would typically be exposed in a real-world environment.

Further, the cords and cables were connected to three different types of circuit protection devices. Therefore, the decision regarding the basic test design was made to expose the six different types of cords, positioned on the floor of a compartment, to a growing fire to determine when and under what conditions the local cord/cable failures would cause the circuit protection devices to trip.

\section{Objectives and Limitations}

The following objectives were developed for this study: determine if there are critical thermal exposure conditions to the cords/cables, determine if the cord/cable type affected the trip type when exposed to fire conditions (recall the three types from Sect. 1), determine if the remote circuit protection type affected trip type when cords/cables were exposed to fire conditions, and determine if a correlation can be made between the cord/cable damage and the trip type. For these experiments, fire conditions were defined by a fuel load in a single compartment sufficient to sustain flashover within that compartment. In addition to the electrical fault related questions, the repeatability of the fire conditions, and the impact of changes to the fuel load within the fire room were examined.

In conducting the experiments detailed in this report, there are several key points that need to be highlighted to ensure there is appropriate context for this work. The circuit protective devices were located at a panel board on an external side wall of the fire compartment and not directly exposed to the same thermal conditions as the cords. In other words, the circuit breakers were unaffected by the fire throughout the test. These experiments were not designed to specifically test the operating performance of circuit breakers. An example would be the electrical setup used in these experiments versus that which is required for AFCIs in UL 1699. There was high available current in these experiments (approximately $750 \mathrm{~A})$ and a short homerun distance $(5.5 \mathrm{~m}(18 \mathrm{ft}))$. The results of these experiments may likely be different using 500 A available short circuit current and a $15.3 \mathrm{~m}(50 \mathrm{ft})$ home run.

A typical installation of NM-B cable in a residential structure would be through a stud, behind gypsum board. The exposed NM-B cables thus had an atypical setup in these experiments, specifically as to link to prior research. Similar to what could occur in a residential structure, there were two-conductor cords connected to both GFCI and ACFI circuits. In these cases, it was not expected that those circuits would behave differently than if connected to an MCCB.

\section{Experimental Configuration}

\subsection{Experimental Room}

A fire room with a single opening was constructed in Underwriters Laboratories' calorimetry laboratory in Northbrook, IL. The laboratory footprint is approxi- 
mately $13.1 \mathrm{~m}(43.0 \mathrm{ft})$ by $14.6 \mathrm{~m}(48.0 \mathrm{ft})$. The calorimeter has the capacity to measure both chemical (oxygen consumption calorimetry) and convective (thermopile calorimetry) heat release rates. The diameter of the smoke collection exhaust hood is $7.6 \mathrm{~m}(25.0 \mathrm{ft})$, and it is positioned approximately $7.6 \mathrm{~m}(25.0 \mathrm{ft})$ from the floor.

The interior dimensions of the test room were $3.7 \mathrm{~m}(12.0 \mathrm{ft})$ by $3.7 \mathrm{~m}(12.0 \mathrm{ft})$ by $2.4 \mathrm{~m}(8.0 \mathrm{ft})$ tall. The only opening measured $2.4 \mathrm{~m}(8.0 \mathrm{ft})$ wide by $2.0 \mathrm{~m}$ $(6.7 \mathrm{ft})$ high and was located on the front wall of the room. The walls and ceiling were lined with one layer of $1.6 \mathrm{~cm}$ (0.625 in.) thick type $\mathrm{X}$ gypsum board and one layer of $1.3 \mathrm{~cm}$ ( $0.5 \mathrm{in}$.) thick conventional gypsum board supported by $3.8 \mathrm{~cm}$ by $8.9 \mathrm{~cm}$ ( 2 in. by 4 in.) wood studs.

The floor was built with $3.8 \mathrm{~cm}$ by $15.2 \mathrm{~cm}$ ( 2 in. by 6 in.) wood joists covered with $1.3 \mathrm{~cm}$ ( 0.5 in.) thick plywood and $1.3 \mathrm{~cm}(0.5 \mathrm{in}$.) thick cement board. The exterior front face of the room was covered with $1.3 \mathrm{~cm}(0.5 \mathrm{in}$.) cement board to prevent fire spread to the exterior of the compartment. Figure 1 shows the dimensions of the room in plan view. For the final experiment, the room was lined with decorative vinyl-laminated medium density fiberboard (MDF) paneling, $3.5 \mathrm{~mm}$ (0.14 in.) thick, with a density of $0.12 \mathrm{~kg} / \mathrm{m}^{3}$ on the three interior walls.

\subsection{Instrumentation}

Temperature and heat flux measurements were taken within the compartment to characterize the thermal environment. Gas temperatures were measured with $1.3 \mathrm{~mm}$ (0.05 in.) diameter, bare-bead, Chromel-Alumel (type K) thermocouples while Schmidt-Boelter gauges were used to measure total heat flux. Results from an international study on total heat flux gauge calibration and response demonstrated that the uncertainty of a Schmidt-Boelter gauge is typically $\pm 8 \%$ [18]. The first heat flux gauge were installed $1.01 \mathrm{~m}$ on center from the side wall of the structure. Each of the gauges were spaced $0.2 \mathrm{~m}$ apart with the top of the gauge flush mounted to the cement board floor. Two thermocouple arrays, with eight thermocouples per array, and nine heat flux gauges were installed in the room. Small diameter thermocouples were used to limit measurement uncertainty, which is estimated to be $\pm 15 \%$ for these experiments $[6,17]$. Figure 1 shows the spatial location of the instrumentation within the test room. The top thermocouple in

\section{Table 1}

Electrical Fault Testing Experiments Fuel Load

\begin{tabular}{llll}
\hline Exp \# & Sofas & Flooring & Lining \\
\hline 1 & 2 & Padding \& Carpet & Gypsum \\
2 & 2 & Padding \& Carpet & Gypsum \\
3 & 2 & Padding \& Carpet & Gypsum \\
4 & 1 & Padding \& Carpet & Gypsum \\
5 & 1 & Padding \& Carpet & Gypsum \\
6 & 2 & Padding \& Carpet & MDF \\
\hline
\end{tabular}




\section{Table 2}

Description of Furnishing and Inferior Finish Fuel Package

\begin{tabular}{|c|c|c|c|c|c|}
\hline Item & Quantity & Material description & Dimensions (m) & $\begin{array}{c}\text { Mass } \\
(\mathrm{kg})\end{array}$ & $\begin{array}{l}\text { Total mass } \\
\qquad(\mathrm{kg})\end{array}$ \\
\hline Sofa & 2 & $\begin{array}{l}\text { Polyester fabric, batting, } \\
\text { PUF }\end{array}$ & $\begin{array}{l}2.20 \mathrm{~L} \text { by } 0.91 \mathrm{D} \text { by } 0.91 \\
\mathrm{H}\end{array}$ & 47.5 & 95.0 \\
\hline Carpet & $8.9 \mathrm{~m}^{2}$ & $\begin{array}{l}100 \% \text { Olefin fiber w/PP } \\
\text { backing }\end{array}$ & $3.68 \mathrm{~L}$ by $6.05 \mathrm{~W}$ & 33.0 & 33.0 \\
\hline Padding & $8.9 \mathrm{~m}^{2}$ & PU foam & $\begin{array}{l}3.66 \mathrm{~L} \text { by } 2.44 \mathrm{~W} \text { by } \\
12.7 \mathrm{~mm} \mathrm{H}\end{array}$ & 7.3 & 7.3 \\
\hline Sub-floor & $8.9 \mathrm{~m}^{2}$ & Oriented strand board & $\begin{array}{l}3.66 \mathrm{~L} \text { by } 2.44 \mathrm{~W} \text { by } \\
17.9 \mathrm{~mm} \mathrm{H}\end{array}$ & 116.0 & 116.0 \\
\hline \multirow[t]{2}{*}{ *Paneling } & $26.7 \mathrm{~m}^{2}$ & $\begin{array}{l}\text { Medium density fiber- } \\
\text { board }\end{array}$ & $\begin{array}{l}2.44 \mathrm{~L} \text { by } 1.22 \mathrm{~W} \text { by } \\
3.5 \mathrm{~mm} \mathrm{H}\end{array}$ & 10 & 89.7 \\
\hline & & & & $\begin{array}{l}\text { Total } \\
\text { Mass }\end{array}$ & 341.0 \\
\hline
\end{tabular}

* Paneling was only used in Experiment 6

each array was located $2.54 \mathrm{~cm}$ (1 in.) below the ceiling with the remaining 7 spaced at $30.5 \mathrm{~cm}(1 \mathrm{ft})$ intervals $(30.5 \mathrm{~cm}$ below ceiling, $61 \mathrm{~cm}$ below ceiling ... $213 \mathrm{~cm}$ below ceiling). For more information regarding the cord exposures, see Sect. 3.4 .

In addition to the instrumentation in the test room, the laboratory was instrumented to capture heat release rate (HRR). The test room was oriented inside the lab such that combustion products produced from the experiments were collected by the $7.6 \mathrm{~m}(25 \mathrm{ft})$ diameter smoke collection exhaust hood. For these experiments oxygen consumption calorimetry was used [9]. To ensure capture of the smoke produced (i.e., quantify the drop in oxygen concentration from combustion products) during the experiments, the exhaust duct was operated at $14 \mathrm{~m}^{3} / \mathrm{s}$ (30,000 CFM). The heat release calorimeter has been calibrated with a steady fire size of approximately $10 \mathrm{MW}$ from a heptane spray burner. Bryant and Mullholland [7] estimate the uncertainty of oxygen consumption calorimeters measuring high heat release rate fires at $\pm 11 \%$.

\subsection{Fuel Load}

The primary fuel load, a three-seat sofa, was chosen to be representative of a residential living room. The wood-based sub-floor was covered with a $12.7 \mathrm{~mm}$ ( 0.5 in.) layer of polyurethane foam padding. The padding was covered with $1.2 \mathrm{~cm}$ ( 0.47 in.) carpeting composed of Olefin fiber attached to a polypropylene backing material. In the sixth experiment, the walls were lined with $3.5 \mathrm{~mm}$ (0.14 in.) vinyl-covered MDF panels. In Experiments 4-5, only one sofa was used instead of two. Table 1 shows the fuel load for each of the experiments.

The sofas were purchased new. The body and the cushions of the sofa were upholstered in $100 \%$ polyester fabric. The seat cushions were filled with $127 \mathrm{~mm}$ 


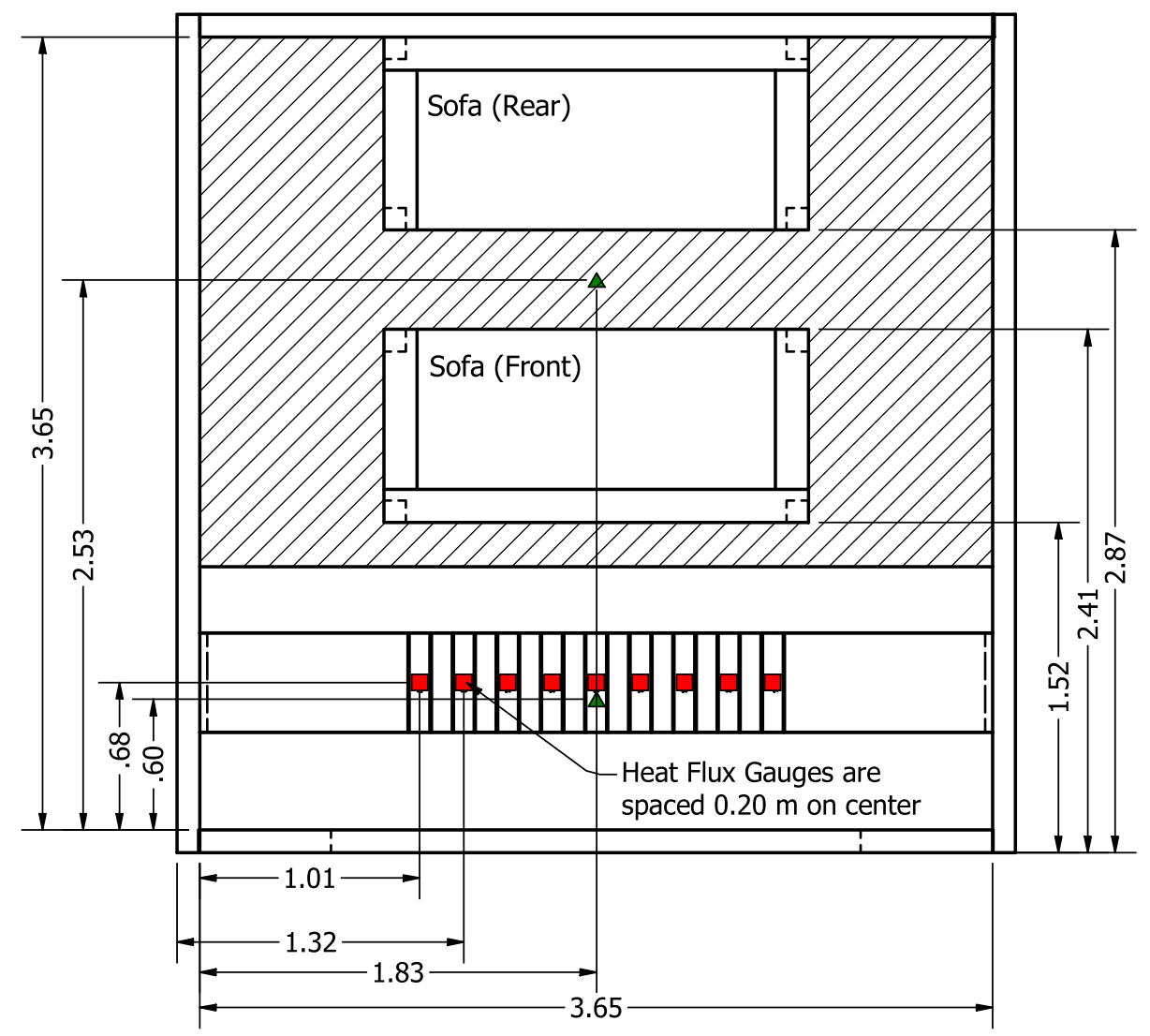

Figure 1. Dimensioned instrumentation configuration. Dimensions are in meters. Red squares between the cords/cables are heat flux gauges and green triangles are thermocouple arrays. The hatched area represented the location of the padding and carpet. Note, there was no front sofa in Experiments 4 and 5.

(5 in.) thick polyurethane foam pads, with a layer of $25 \mathrm{~mm}$ (1 in.) polyester batting on the top and bottom of the polyurethane pads. The back cushions were filled with polyester batting. Table 2 provides detailed information regarding the composition and mass of the fuel used in the experiments. Recall from Fig. 1, the location of the sofa(s) as well as the padding and carpet.

To understand the magnitude and repeatability energy release of the primary fuel package used in these experiments, three sofas were ignited with an electric matchbook and burned in the absence of a compartment and quantified using oxygen consumption calorimetry. The heat release rate (HRR) as a function of time for the three sofas is included in Fig. 16 in Appendix 1.

Sofa 1 had a peak HRR of $2.5 \mathrm{MW}$ while the peak HRR for sofa 2 and sofa 3 were 4.1 MW and 4.2 MW, respectively. The peak HRR for sofas 2 and 3 were within the typical uncertainty of the measurement. The peak HRR from sofa 1 


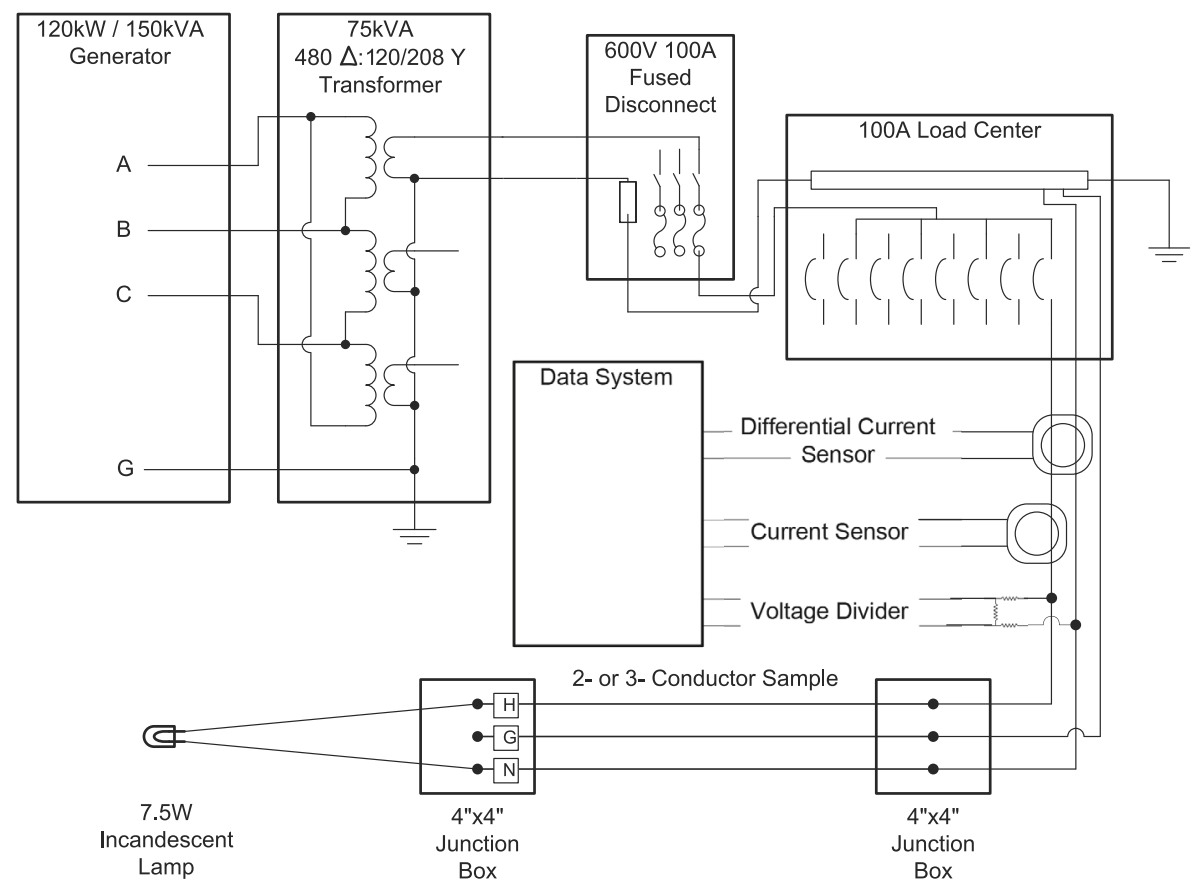

Figure 2. Line drawing schematic of the electrical test sefup. The system was powered by 120 kW/1 50 kVA, 3-phase AC generator. Three subpanels (100 A load center) were each supplied by one phase of a $75 \mathrm{kVA}, 120 / 208 \mathrm{~V}$ wye transformer with $100 \mathrm{~A}$ time-delay fuses installed between the subpanels and the transformer. 18 circuits were installed to examine 6 cords/cables and 3 circuit breakers which were equipped with a voltage sensing circuit that had a resistive voltage-divider to reduce signal levels for measurement purposes. Each circuit terminated at $7.5 \mathrm{~W}$ incandescent bulb for visual indication of live circuits. For 3-conductor circuits, the third insulated conductor was connected to the 'hot'.

was approximately $40 \%$ lower than the other two sofas, which highlights the natural variability of fuel. An integration over time for the HRR was conducted to calculate the total energy release. The total energy release showed similarity $(10 \%$ difference) between all three sofas. Table 3 shows the peak HRR and total energy release for each sofa.

\subsection{Electrical Test Configuration}

To ensure any concurrent experiments within the laboratory did not impact the electrical configuration for these experiments and to match the impedance of a typical residential home, the system was powered by $120 \mathrm{~kW} / 150 \mathrm{kVA}$, 3-phase AC generator. Figure 2 is a line drawing schematic of the electrical test setup. 


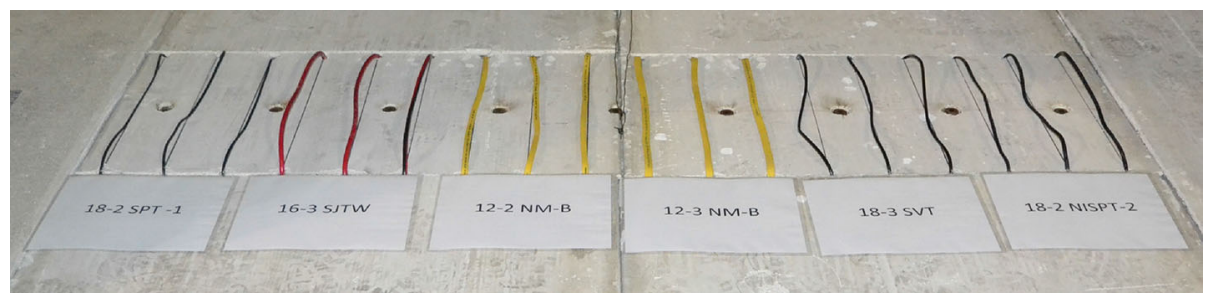

Figure 3. Photograph of the 18 cord/cable exposures in the test room prior to the start of the test. The placards identify the cord/cable type.

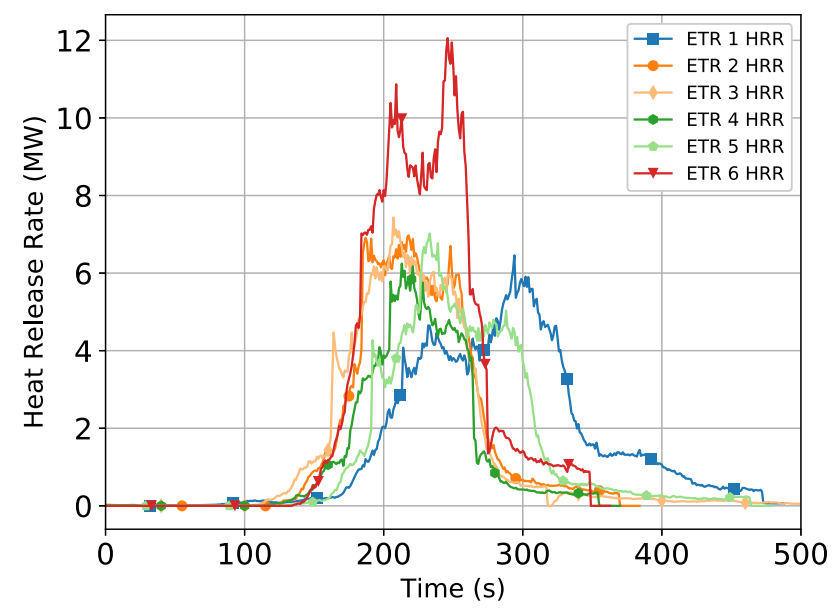

Figure 4. Heat release rate versus time for each of the six experiments. The uncertainty of the heat release rate measurements is estimated to be $\pm 11 \%$.

Three subpanels (100 A Load Center in Fig. 2) were each supplied by one phase of a $75 \mathrm{kVA}, 120 / 208 \mathrm{~V}$ wye transformer. A fused disconnect, with $100 \mathrm{~A}$ time-delay fuses, was installed between the subpanels and the transformer. These fuses were selected to minimize the chance of "blowing" on a short-term heavy overload as from a short-circuit in a sample cable or cord.

The available fault current in each circuit, calculated by loading the circuits and measuring voltage drop, ranged from $738 \mathrm{~A}$ to $752 \mathrm{~A}$. Appendix 2 provides the data (Table 9) and definitions (Table 10) used to calculate the fault current within each of the circuits. Within each subpanel were two groups of three circuit breakers. Each group of three circuit breakers supplied specimens of one of the six cord types. For each cord/cable type, three different breakers were installed.: a conventional thermal/magnetic breaker (MCCB), a ground-fault circuit interrupter (GFCI) breaker, and an arc-fault circuit interrupter (AFCI) breaker which also 


\section{Table 3}

Sofa HRR Dała-Pre-suppression Peak HRR and Tołal Energy Released

\begin{tabular}{lll}
\hline Sofa $\#$ & Peak HRR $(\mathrm{MW})$ & Total energy released (MJ) \\
\hline 1 & 2.5 & 655 \\
2 & 4.1 & 649 \\
3 & 4.2 & 639 \\
\hline
\end{tabular}

\section{Table 4}

Electrical Fault Test Setup-Circuit, Breaker, And Cord/Cable

\begin{tabular}{lll}
\hline Circuit number & Breaker type & Cord/Cable type \\
\hline 1 & MCCB & $18-2$ SPT1 \\
2 & AFCI & $18-2$ SPT1 \\
3 & GFCI & $18-2$ SPT1 \\
4 & MCCB & $16-3$ SJTW \\
5 & AFCI & $16-3$ SJTW \\
6 & GFCI & $16-3$ SJTW \\
7 & MCCB & $12-2$ NM-B \\
8 & AFCI & $12-2$ NM-B \\
9 & GFCI & $12-2$ NM-B \\
10 & MCCB & $12-3$ NM-B \\
11 & AFCI & $12-3$ NM-B \\
12 & GFCI & $12-3$ NM-B \\
13 & MCCB & $18-3$ SVT \\
14 & AFCI & $18-3$ SVT \\
15 & GFCI & $18-3$ SVT \\
16 & MCCB & $18-2$ NISPT-2 \\
17 & AFCI & $18-2$ NISPT-2 \\
18 & GFCI & $18-2$ NISPT-2 \\
\hline
\end{tabular}

had a ground-fault protection built in. All of the circuit breakers were rated for $20 \mathrm{~A}$. All of the 18 circuits were supplied through $5.49 \mathrm{~m}(18 \mathrm{ft})$ lengths of 142 NM-B cable with grounding conductors. ${ }^{1}$ The wiring samples were connected to the NM-B cable in individual electrical boxes installed beneath the floor and run up through openings in the floor. Each cord specimen had a length of $0.46 \mathrm{~m}$ (18 in.) exposed above the floor. The cord/cable specimens were then run down through openings in the floor to another set of individual electrical boxes. From the second set of electrical boxes beneath the floor, $5.79 \mathrm{~m}(19 \mathrm{ft})$ lengths of 14$2 \mathrm{NM}-\mathrm{B}$ cable were run to 18 lamp sockets, each equipped with a $7.5 \mathrm{~W}$ incandescent bulb for visual indication of live circuits.

Note that in Fig. 2 only one of the three circuit subpanels is shown. While only one sample is shown as 'wired' to a light bulb, all 18 samples were connected to

\footnotetext{
${ }^{1}$ These experiments were not specifically designed to directly assess the performance of circuit protection devices. The results of this experiments may be different with different electrical configurations such as the $500 \mathrm{~A}$ available fault current and $15 \mathrm{~m}$ to $21 \mathrm{~m}$ (50 ft to $70 \mathrm{ft}$ ) home run length as defined by UL 1699.
} 


\section{Table 5}

Description of Cord/Cable Type Examined

\begin{tabular}{llcc}
\hline Type & \multicolumn{1}{c}{ Insulation } & Voltage rating & Temperature rating \\
\hline SPT1 (cord) & Thermoplastic cord, parallel jacketed & $300 \mathrm{~V}$ & $105^{\circ} \mathrm{C}$ \\
SJTW (cord) & Thermoplastic hard jacket, water resistant & $300 \mathrm{~V}$ & $105^{\circ} \mathrm{C}$ \\
NM-B (cable) & Non-metallic sheathed, thermoplastic insulated & $600 \mathrm{~V}$ & $90^{\circ} \mathrm{C}$ \\
SVT (cord) & Thermoplastic jacket, service vacuum & $300 \mathrm{~V}$ & $105^{\circ} \mathrm{C}$ \\
NISPT-2 (cord) & Non-integral service parallel thermoplastic & $300 \mathrm{~V}$ & $105^{\circ} \mathrm{C}$ \\
\hline
\end{tabular}
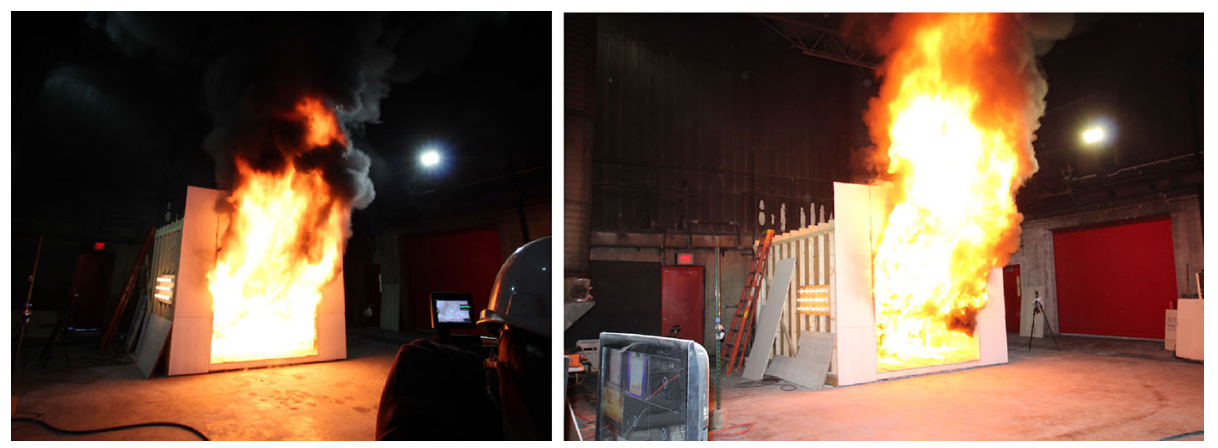

Figure 5. Photographs of the room during flashover, immediately prior to any of the circuits tripping-Experiment 5 (left) and Experiment 6 (right).
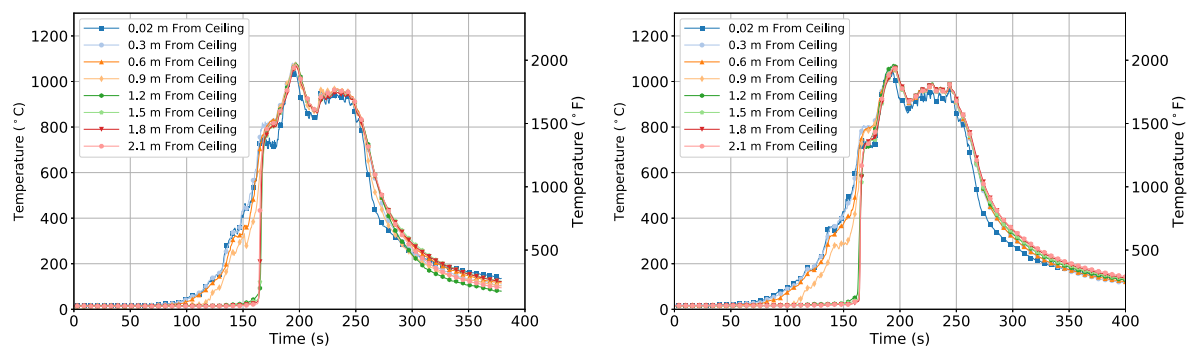

Figure 6. Experiment 2 (left) and Experiment 3 (right)-thermocouple temperature time-history at the mid-room location. At this location, there were 8 thermocouples; the top thermocouple was $0.02 \mathrm{~m}$ from the ceiling and the subsequent 7 were in $0.3 \mathrm{~m}$ intervals from the ceiling. The uncertainty of the thermocouple measurements is estimated to be $\pm 15 \%$. 

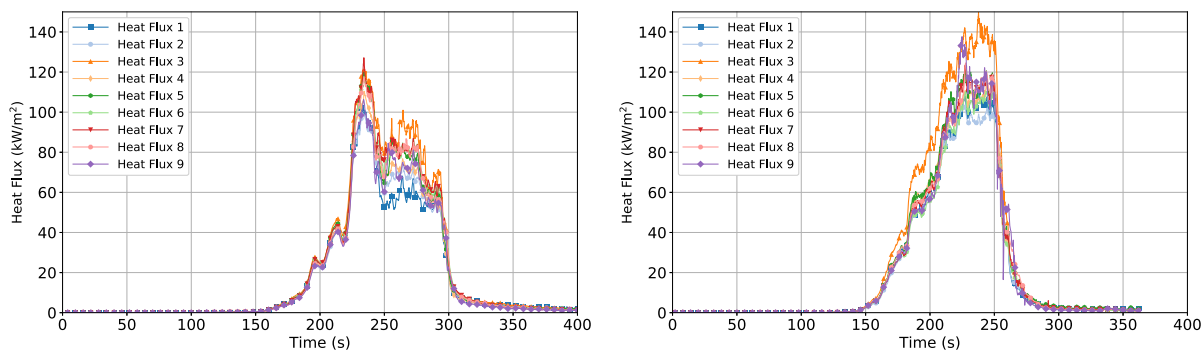

Figure 7. Experiment 5 (left) and Experiment 6 (right)-heat flux time-history at the floor near the vent opening. Heat flux gauges were spaced between every two cables/cords such that there were 9 gauges for 18 samples. The uncertainty of the heat flux measurements is estimated to be $\pm 8 \%$.
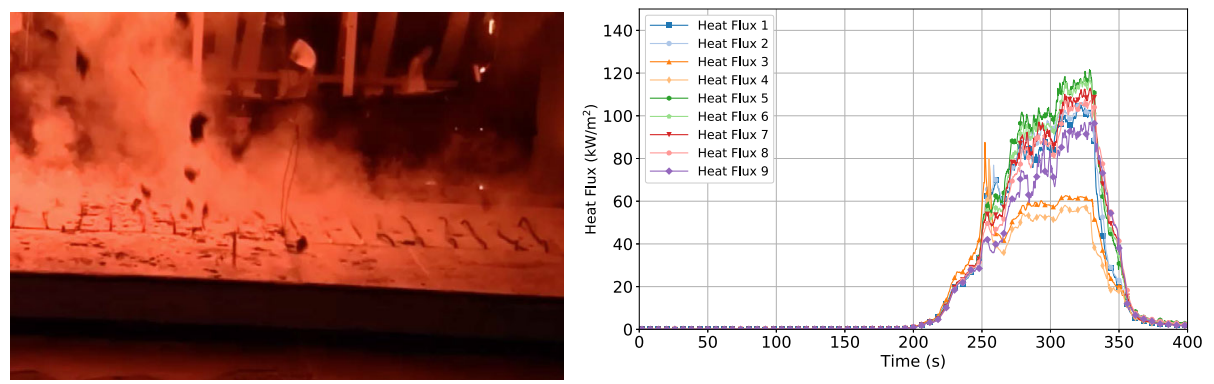

Figure 8. Experiment 1-Debris falling from ceiling onfo heat flux gauge 3 (left) and the impact on heat flux time history (right). Heat flux gauges were spaced between every two cables/cords such that there were 9 gauges for 18 samples. The uncertainty of the heat flux measurements is estimated to be $\pm 8 \%$.

an incandescent light bulb. Three subpanels, each supplied six samples which resulted in 18 total exposed cords per experiment.

Each of the 18 circuits were equipped with a voltage sensing circuit that had a resistive voltage-divider to reduce signal levels for measurement purposes. Gain levels were determined for all circuits with a resistive load between line and ground. Voltage measurements were utilized solely in determining the status of the circuit breakers, indicating either a closed or open condition. Clamp-on current sensors were used for measuring fault currents in the line (hot) wire, with gain levels determined by manufacturer's specifications. Fault current measurements were utilized only in determining the cause of the circuit breaker trips. Finally, differential current sensors comparing the current in the line conductor to the current in the neutral conductor were used. A schematic of the measurements is included in Fig. 2. 


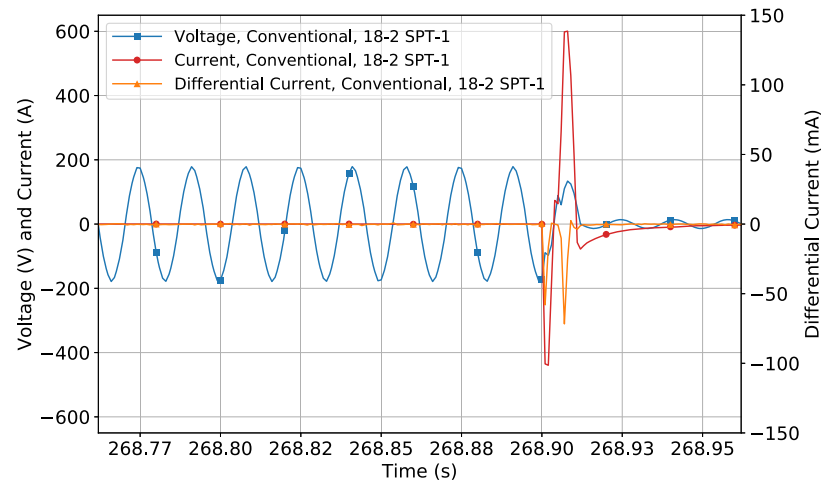

Figure 9. Experiment 1-Signal data of an MCCB with $18-2$ SPT 1 cord (Circuit 1) that had an over-current trip.

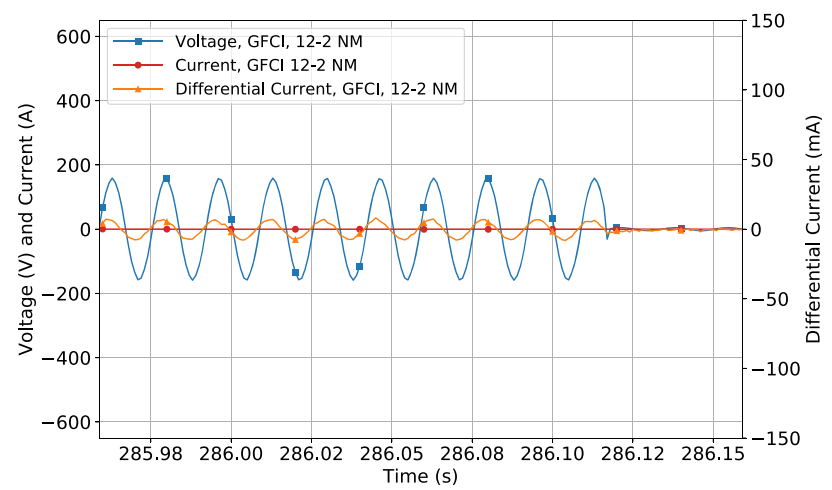

\section{Figure 10. Experiment 1-Signal data of a GFCI breaker with 12-2 NM-B cable (Circuit 9 ) that had a ground fault trip.}

Gain levels were determined for all circuits with a resistive load between line and ground (Table 11). As a result of the gain level measurements, differential current magnitude trip levels for all GFCI breakers were confirmed to be greater than $4 \mathrm{~mA}_{\mathrm{RMS}}$ and less than $10 \mathrm{~mA}_{\mathrm{RMS}}$, while trip levels for all AFCI breakers were confirmed to be greater than $10 \mathrm{~mA}_{\mathrm{RMS}}$.

In circuits with 3-conductor cord specimens, a measured differential current would indicate ground-fault conditions, as the line and neutral currents would become unequal. The inequality in currents would indicate an alternate electrical path, specifically ground. In circuits with 2-conductor cord samples, no differential current could be measured, as there were no electrical paths to ground through the cable, however other pathways were possible. The system is center-tapped ground so there could be line-to-line faults or line-to another circuit's neutral. Based on the spacing between samples and 'tight' install in the floor, line-to another circuit's neutral was not expected. The data were collected with a com- 


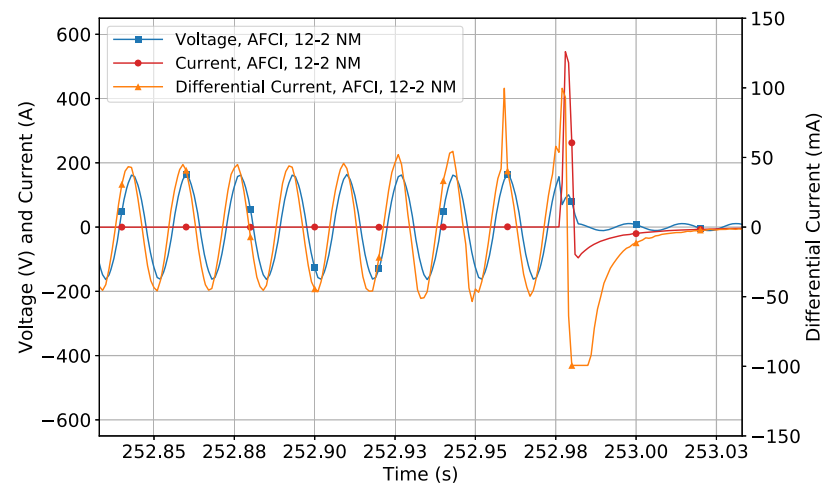

Figure 11. Experiment 5-Signal data of a AFCI breaker with $12-2$ NM-B cable (Circuit 8) that had an over-current trip.

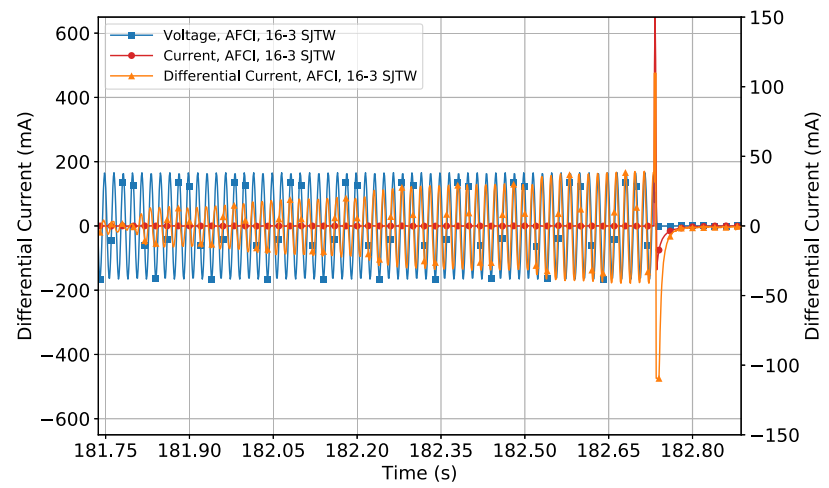

\section{Figure 12. Experiment 6-Signal data of a AFCI breaker with $16-3$ SJTW cord (Circuit 5) that showed signs of a ground-fault but had an over-current trip.}

puter-based data acquisition system that collected a thousand readings per second. The fast data collection rate was necessary to capture the shape of the electric waveforms so that the cause of the circuit fault could be determined.

Table 4 shows the breakdown of 18 configurations: circuit number, breaker type, and cord/cable type.

In the cord/cable type column the first two numbers define the gauge (diameter) and the number of conductors in the cord/cable, respectively. The text string portion of the cord/cable type in Table 4 defines the insulation and temperature rating of the cords. The four cords and two cables tested had temperate ratings that ranged between $90^{\circ} \mathrm{C}$ and $105^{\circ} \mathrm{C}$. Table 5 describes the insulation, voltage rating, and temperature rating of the cords and cable. 


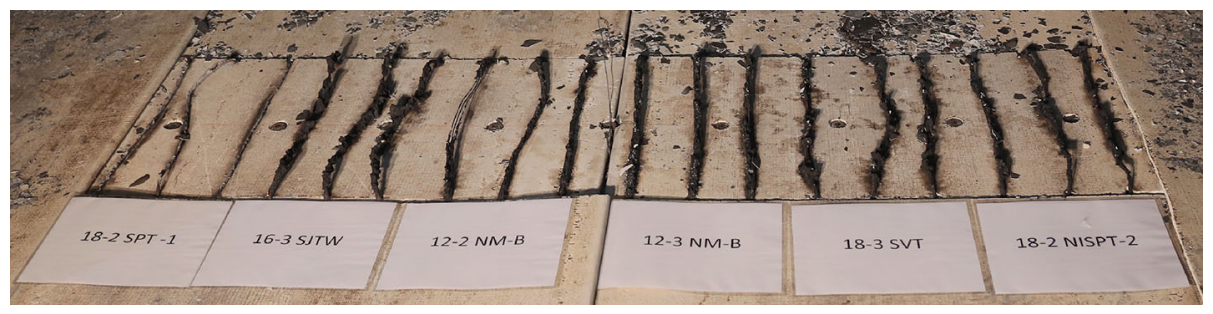

Figure 13. Photograph of the 18 cord/cable exposures in the test room following Experiment 2. The placards identify the cord/cable type.

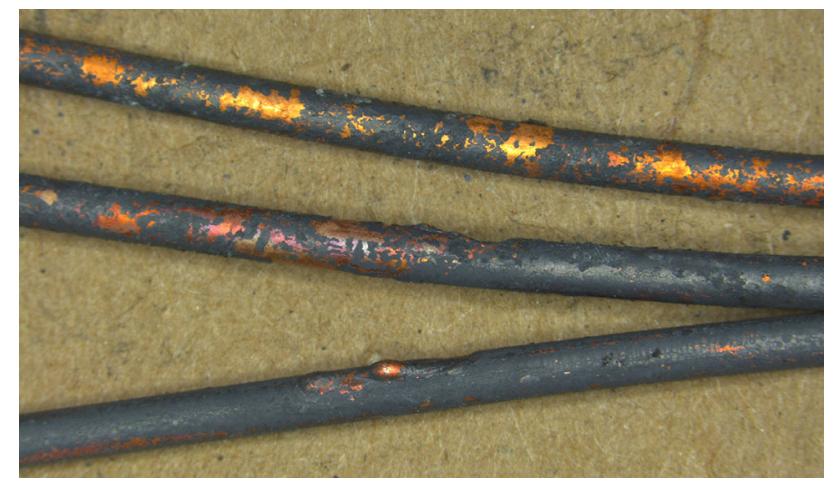

Figure 14. Magnified photograph of the $12-2$ NM-B cable on an MCCB (Circuit 7 ) following Experiment 2 showing both a bead and a notch on the conductor.

The cords and cables were installed on the floor of the structure, $0.45 \mathrm{~m}$ (18 in.) from the opening. The cords/cables were spaced $0.1 \mathrm{~m}$ (4 in.) apart on center with the first cord/cable $0.96 \mathrm{~m}$ (38 in.) from the left side wall. Each cord/cable had an exposure length of $0.45 \mathrm{~m}$ (18 in.). Figure 3 shows a photograph of the installed cords and cables prior to an experiment. Note the presence of heat flux gauges installed in the floor between every other cord/cable.

\subsection{Test Procedure}

All ignitions were started in the center seat cushion of the rear sofa with an electric match. The fires were allowed to grow until all of the circuits had faulted, at which point the power was disconnected and the fire suppressed with water. The suppression was conducted with a low flow nozzle, less than $20 \mathrm{gpm}$. The firefighters were directed to apply the water in a manner that would not impact the cord samples. After the fire was extinguished, the cords were photographed in place and then collected for further examination in the laboratory. 


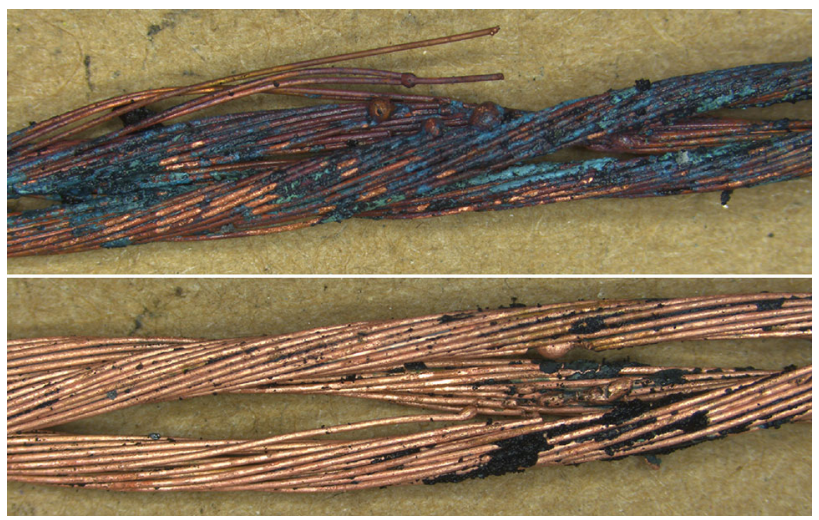

Figure 15. Magnified photograph of the 16-3 SJTW cord on a MCCB following Experiment 1, Circuit 4 (top) and on a GFCI following Experiment 4, Circuit 6 (bottom).

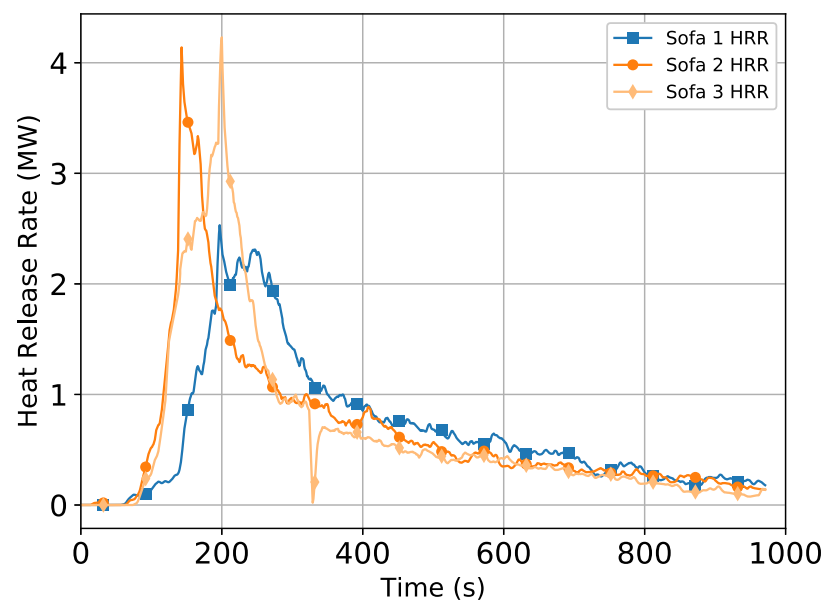

Figure 16. Heat release rate versus time replicates for sofas used in experiments. The uncertainty of the heat release rate measurements is estimated to be $\pm 11 \%$.

\section{Results}

\subsection{Thermal Exposure}

Figure 4 shows the heat release versus time for the six experiments. For the six experiments conducted, Experiments 1-3 were replicates (Table 1) of the two sofa fuel load. Experiments 4 and 5 were replicates using the reduced fuel load (single sofa) while Experiment 6 had an increased fuel load with the addition of MDF paneling to examine if the additional fuel load had different results. 


\section{Table 6}

Peak HRR, Total Energy, and Time to Trip from the Room Experiments

\begin{tabular}{lcccc}
\hline Exp \# & $\begin{array}{c}\text { Peak HRR (MW) } \\
\text { Prior to suppression }\end{array}$ & $\begin{array}{c}\text { Total energy released } \\
\text { Prior to first trip (MJ) }\end{array}$ & Time to first trip (s) & Time to last trip (s) \\
\hline 1 & 6.5 & 285 & 267 & 314 \\
2 & 7.0 & 264 & 205 & 235 \\
3 & 7.4 & 220 & 202 & 236 \\
4 & 6.2 & 211 & 210 & 235 \\
5 & 7.0 & 245 & 238 & 267 \\
6 & 12.0 & 244 & 206 & 245 \\
\hline
\end{tabular}

\section{Table 7}

Circuit Trip Type for Each Cord/Cable and Break for Each Experiment

\begin{tabular}{lllllllll}
\hline \multirow{2}{*}{$\begin{array}{l}\text { Circuit } \\
\text { Number }\end{array}$} & $\begin{array}{c}\text { Breaker } \\
\text { Type }\end{array}$ & $\begin{array}{c}\text { Cord/cable } \\
\text { Type }\end{array}$ & Exp 1 & Exp 2 & Exp 3 & Exp 4 & Exp 5 & Exp 6 \\
\cline { 5 - 9 } 1 & MCCB & 18-2 SPT1 & OC & OC & OC & OC & OC & OC \\
2 & AFCI & $18-2$ SPT1 & OC & OC & OC & OC & OC & OC \\
3 & GFCI & 18-2 SPT1 & OC & OC & OC & OC & OC & OC \\
4 & MCCB & $16-3$ SJTW & OC & OC & OC & OC & OC & OC \\
5 & AFCI & $16-3$ SJTW & OC & OC & OC & OC & OC & OC \\
6 & GFCI & $16-3$ SJTW & OC & OC & OC & OC & OC & OC \\
7 & MCCB & $12-2$ NM-B & OC & OC & OC & OC & OC & OC \\
8 & AFCI & $12-2$ NM-B & GF & GF & GF & GF & OC & GF \\
9 & GFCI & $12-2$ NM-B & GF & GF & GF & GF & GF & GF \\
10 & MCCB & $12-3$ NM-B & OC & OC & OC & OC & OC & OC \\
11 & AFCI & $12-3$ NM-B & OC & GF & GF & OC & GF & GF \\
12 & GFCI & $12-3$ NM-B & GF & GF & GF & GF & GF & GF \\
13 & MCCB & $18-3$ SVT & OC & OC & OC & OC & OC & OC \\
14 & AFCI & $18-3$ SVT & OC & OC & OC & OC & OC & OC \\
15 & GFCI & $18-3$ SVT & OC & OC & OC & OC & OC & OC \\
16 & MCCB & $18-2$ NISPT-2 & OC & OC & OC & OC & OC & OC \\
17 & AFCI & $18-2$ NISPT-2 & OC & OC & OC & OC & OC & OC \\
18 & GFCI & $18-2$ NISPT-2 & OC & OC & OC & OC & OC & OC \\
\hline
\end{tabular}

$O C$ over-current trip, $G F$ ground-fault trip

The heat release rate growth was similar for all six experiments as shown in Fig. 4. The peak HRR values for Experiments 1-5, shown in Table 6, have a standard deviation of $475 \mathrm{~kW}$, within the $11 \%$ uncertainty measurement capability of the calorimeter of the laboratory. Recall the peak HRR of the sofa from Table 3 compared to peaks from the compartment experiments. In these experiments, the padding and capret as well as compartment effects contributed to the higher heat release rates. The removal of a sofa in Experiments 4 and 5 did not have a significant impact on peak release rate prior to suppression compared to Experiments 1- 


\section{Table 8 \\ Mean and Standard Deviation at Trip of Integrated Heat Flux for Each Cord/Cable Type at Trip}

\begin{tabular}{lcc}
\hline \multirow{2}{*}{ Type } & \multicolumn{2}{c}{ Integrated heat flux } \\
\cline { 2 - 4 } & Mean $\left(\mathrm{MJ} / \mathrm{m}^{2}\right)$ & Std. Dev $\left(\mathrm{MJ} / \mathrm{m}^{2}\right)$ \\
\hline 18-2 SPT1 & 22.8 & 4.6 \\
16-3 SJTW & 48.9 & 9.4 \\
12-2 NM-B & 35.3 & 4.8 \\
12-3 NM-B & 35.9 & 8.9 \\
18-3 SVT & 28.4 & 3.7 \\
18-2 NISPT-2 & 30.7 & 4.4 \\
\hline
\end{tabular}

3 where two sofas were used. To further assess heat release, the data were integrated over time from ignition to time of first trip to calculate a total energy release for each experiment. Due to suppression actions, it was impractical to integrate over the total burn duration. The average total energy released prior to first trip was $245 \mathrm{MJ}$ with a standard deviation of $28 \mathrm{MJ}$. The standard deviation is on par with the uncertainty measurement capability of the calorimeter of the laboratory. Table 6 also included the time of the first and last trip for each experiment which shows that the time between the trips ranged between $30 \mathrm{~s}$ and $40 \mathrm{~s}$.

For Experiment 6, however, the distribution of fuel within the compartment (fuel around the perimeter of the room and floor to ceiling) changed due the addition of MDF paneling on the walls. This led to an increase in burning exterior to the compartment as shown in the comparison images between Experiments 5 and 6 in Fig. 5. Figure 5 shows the fire external to the room in both Experiments 5 and 6 prior to any of the circuits being tripped. Outside of Experiment 1 , which had a slower initial growth as the fire initially burned in depth in the seat cushion versus burning into the back cushion; fire was first visible outside of the compartment at approximately 2:45 (165 s) after ignition. As all of the fuel loads were sufficient to transition the room to flashover, external burning was a product of excess fuel and the fixed ventilation opening.

To limit unnecessary damage to the exposed cords after all circuits had tripped, the fires were suppressed rather than allow for all of the fuel to be consumed. This is noticeable in the sharp declines in HRR in Fig. 4. For suppression, the stream was directed off of the ceiling and walls until the surfaces were cooled followed by directing the stream onto the burning contents for final extinguishment. Care was taken during suppression actions to avoid direct contact from the stream to the exposed cord samples. Note, prior to suppression, power was disconnected from the circuits at the load center after the last circuit had tripped.

While there was consistency in the HRR growth for all experiments and peak values for Experiments 1-5, that measurement alone cannot quantify similarities in fire behavior within the room. This is due in part to the significant amount of combustion that occurred external to the room (Fig. 5). Therefore, the mid-room thermocouple array was also used to assess the repeatability of the thermal conditions within the compartment. All six experiments showed similar temperature 
behavior, and Fig. 6 shows the thermocouple time-history from Experiments 2 and 3 as representative examples. At approximately $160 \mathrm{~s}$ post ignition in Experiments 2 and 3 (see Fig. 6), the temperatures from $1.2 \mathrm{~m}$ to $2.1 \mathrm{~m}$ from the ceiling all rise to greater than $600^{\circ} \mathrm{C}$, an indication that the room transitioned to flashover.

To ensure that cords at the end positions (e.g. 1 and 18) did not "see" different heat fluxes compared to the cords in the center, it was important for the heat flux exposure at the floor to be spatially consistent. Consider the time history of heat flux for each gauge from Experiments 5 and 6, which have the minimum and maximum fuel load, respectively. Figure 7 shows that while the peak values vary between the experiments (recall heat release data in Fig. 4) the mean heat flux sits within the uncertainty of measurements.

In Experiments 1, 2, and 3, however, there was debris that fell from the ceiling. The debris (Fig. 8 left) landed overtop some of the heat flux gauges effectively lowering the heat flux measurement from the gauge. In Experiment 1, heat flux gauges 3 and 4 both had debris land on top of them. Figure 8 (right) shows the lower values of gauges 3 and 4 through the time history of the experiment.

Since the remainder of the heat flux gauges were not covered by debris and Experiments 4, 5, and 6 showed that without debris the heat flux gauge is spatially consistent, cords $5 \& 6$ and $7 \& 8$ were mapped to the heat flux gauges 2 and 5 , respectively. For Experiment 3, the heat flux gauges which were covered by debris were gauges 3 and 5 . Cords $5 \& 6$ and $9 \& 10$ were mapped to heat flux gauges 4 and 6, respectively. In Experiment 2, the debris was sufficient to impact a majority of the heat flux gauges. As a result, the heat flux data from Experiment 2 is not included in aggregate analysis. This did not preclude the electrical trip data from being analyzed. It is important to note that while debris fell during experiments, there was $0.46 \mathrm{~m}$ (18 in.) of exposed cable for each cord and the majority of the cord remained exposed through the duration of the experiment. Analysis of trip times for experiments where there was debris versus experiments where there was no debris did not result in any outliers with respect to trip times.

\subsection{Electrical Response}

All of the breakers tripped on either high-current fault (over-current trip) or ground-fault conditions. An over-current trip occurred when the breaker cleared a fault within 1/2 electrical cycle due to a spike in current. An over-current trip was identified in the signal data by a spike in the current coupled with a drop in the voltage signal. A ground-fault trip was identified in the signal response with a current return to ground coupled with a drop in the voltage signal. While there was evidence of electrical arcing from the physical inspection of the wires (see Sect. 5.2), examination of the waveforms at the time as which the circuits tripped did not did not show signs of an arc fault such as the shouldering of the voltage signal. Figure 9 shows an over-current trip from Experiment 1 for Circuit 1: the 18-2 SPT1 cord with an MCCB.

No arc-fault trips were confirmed. Based on the electrical setup in these experiments (high supply current and AFCI at the panel board with a short homerun), 
these results were not unexpected. All of the AFCI breakers tripped either due to a ground-fault condition or due to a high-current fault. The brand and model of AFCI selected for these experiments, while not marketed as an AFCI/GFCI, did have ground-fault detection incorporated within its arc fault detection algorithm. This helps the AFCI detect parallel arcing conditions for faults that arc from ungrounded to grounding conductor (three conductor cord, typically). It is important to recognize that this does not apply to all parallel arcs since they can also arc from line to neutral. However, the ground fault level for an AFCI may be set higher than the $5 \mathrm{~mA} \pm 1 \mathrm{~mA}$ level typical of residential GFCIs. The difference is because a GFCI is designed for personal protection while differential fault current detection in an AFCI is arc fault protection that happens to be a ground fault condition.

These experiments demonstrate the existence of ground-fault detection circuitry within the chosen AFCI breakers, as well as the difference in ground-fault trip levels between GFCI and AFCI breakers. Ground-fault trips exclusively occurred with NM-B cable, and all NM-B cables with GFCI breakers tripped on ground faults. Figure 10 shows a ground-fault trip from Experiment 1 for Circuit 9: the 12-2 NM-B cable with a GFCI breaker.

Note, not all NM-B circuits protected by AFCI breakers tripped on groundfaults. There were three examples of AFCI breakers with NM-B cable which tripped via over-current: Experiment 1-12-3 NM-B cable; Experiment 4-12-3 NMB cable; and Experiment 5-12-2 NM-B cable. Data from these samples include high leakage currents, clipping of the differential current sensor signals, and current spikes of greater than $300 \mathrm{~A}^{2}{ }^{2}$ Figure 11 shows that in Experiment 5 Circuit 8, the 12-2 NM-B cable with an AFCI circuit, tripped with a current spike of $546 \mathrm{~A}$. Also shown is the clipping of the differential current signal at $99.7 \mathrm{~mA}$. There are also signs of the differential current lagging (out of phase with) voltage. That is indicative of inductance, which could be from a number of sources, including the transformer, cabling, or sensors.

Additionally, there were three cases (two AFCI, one MCCB) where 3-conductor cord could have potentially had a ground-fault failure had the circuit been a GFCI. Note, the ground-fault trip thresholds for the AFCI breakers were higher than for the GFCI breakers. Two of these cases occurred with SJTW cord (Experiment 1, Circuit 4-16-3 SJTW, MCCB and Experiment 6, Circuit 5-16-3 SJTW, AFCI) and one with an SVT cord (Experiment 2, Circuit 14-18-3 SVT, AFCI). Figure 12 shows the voltage, current, and differential current for Experiment 6, Circuit 5-16-3 SJTW with an AFCI breaker. In all three of these cases, there were escalating differential currents prior to the over-current trip as shown in Fig. 12, as well as peak RMS differential current values over the ground-fault threshold for the GFCIs used. The experiments revealed that it cannot be assumed that because an AFCI or GFCI circuit tripped, that it was a result of an arc-fault or a ground-fault. There are a few different tripping mechanisms for a GFCI (thermal, magnetic, ground-fault) and for AFCI (thermal, magnetic,

\footnotetext{
${ }^{2}$ Note that UL 489 does not specify instantaneous trip levels. Had different circuits been chosen, the instantaneous trip levels may have been different.
} 
ground-fault, arc-fault). Additionally, standards such as UL 1699 do not specify the need for any ground-fault trip in an AFCI and manufacturers typically do not disclose trip algorithms in AFCIs.

In each of the six experiments, the 18-2 SPT-1 was the first cord to trip a circuit protection device and the 16-3 SJTW cord was the last. The circuit protection device types for the cords that tripped first and last varied by test. In other words, for the particular cords, one circuit device was not more or less susceptible to tripping. For an overall view of trip type for the 18 exposed cord/cable and breaker configurations, see Table 7. Additionally, specific trip data (time, heat flux, current, and differential current) for each configuration for each experiment is included in Appendix 4 in Tables 12, 13, 14, 15, 16 and 17. Note that time in Tables 12, 13, $14,15,16$ and 17 is time from the ignition of the sofa which is not a the same as exposure time as there is a lag associated with fire growth of the sofa.

\section{Discussion}

\subsection{Heat Flux Analysis}

The time history of heat flux provided insight into exposure, specifically the rapid rise in heat flux as the compartment transitioned to flashover. One indicator for flashover is a heat flux of $20 \mathrm{~kW} / \mathrm{m}^{2}$ [16] at the floor. While the lowest instantaneous heat flux at the time of first trip being greater than $70 \mathrm{~kW} / \mathrm{m}^{2}$ indicates that flashover occurred, the instantaneous heat flux does not completely describe the exposure. A time integrated heat flux which quantifies the duration exposure until the circuit breaker tripped is a more meaningful description. Recall from Fig. 7, the temporal heat flux data from Experiments 5. The heat flux grew until peak heat fluxes occurred at approximately $225 \mathrm{~s}$ post ignition and then dropped to fairly steady values for $50 \mathrm{~s}$ before suppression actions were taken after $300 \mathrm{~s}$. In Experiment 5, the earliest trip occurred at $237 \mathrm{~s}$ post ignition (see Table 16), approximately $12 \mathrm{~s}$ after the peak values were reached. Table 8 shows the average integrated heat flux and standard deviation as function of the six exposed cord types at the time of trip.

It was not expected that different cords, with different thermal masses, would behave the same way when exposed to heat. The measured integrated heat flux data in Table 8 shows overlap in the data for the post-flashover exposures. One note is that circuits connected in series to the 18-2 SPT1 cord tripped first and the circuits connected in series to the 16-3 SJTW cord were the last to trip. The integrated heat fluxes ranges corresponding to these times, did not overlap.

Novak tested energized 14-2 NM-B cables, which were similar to the 12-2 NM-B cables used in this study in terms of both having $90^{\circ} \mathrm{C}\left(194^{\circ} \mathrm{F}\right)$ rated conductor insulation enclosed within an overall non-metallic flame retardant PVC jacket. Novak exposed the energized cables to steady state radiant heat fluxes that ranged from $22 \mathrm{~kW} / \mathrm{m}^{2}$ to $55 \mathrm{~kW} / \mathrm{m}^{2}$. Above $26 \mathrm{~kW} / \mathrm{m}^{2}$, Novak's data showed a significant decrease in time to failure of the cables [14, 15]. Integrating the heat flux exposure from Novak's set of tests yielded a mean of $17.3 \mathrm{MJ} / \mathrm{m}^{2}$ with a standard deviation of $9.2 \mathrm{MJ} / \mathrm{m}^{2}$. The total exposure energy needed to result in a fault was approximately one half of the values for the NM-B cables used in this current study. 
Based on the information from the Safety Engineering Laboratories study on appliance power cords (SPT-1 and SPT-2) exposed to a steady state $40 \mathrm{~kW} / \mathrm{m}^{2}$ radiant exposure [8], the range of total heat exposures ranged from $9.6 \mathrm{MJ} / \mathrm{m}^{2}$ to $15.8 \mathrm{MJ} / \mathrm{m}^{2}$. Although a one to one comparison can't be made, the appliance power cords tested in the current set of experiments had mean total heat exposure values ranging from $22.8 \mathrm{MJ} / \mathrm{m}^{2}$ to $30.7 \mathrm{MJ} / \mathrm{m}^{2}$. It is of interest that the peak values from the compartment fire experiments were more than twice the values of the bench scale steady state exposures.

\subsection{Physical Inspection of Cords/Cables}

Further analysis on potential correlations between circuit trip type, cord/cable type, and thermal exposure was conducted by physical examination of the cords/cables under a microscope following each experiment. Figure 13 is a photograph of the exposed cords still in place following Experiment 2. The placards in front of the cords/cables identify the type.

Following each experiment, the remains of each cord/cable were carefully removed from the floor to limit potential damage to the cords/cables to only that which was caused by the fire. Each cord/cable was cleaned to remove large debris. The cords/cables were then photographed using an 8x magnification digital microscope. From these images, beads, notches, and broken strands were able to be clearly identified. While the damage to the conductors was consistent with electrical arcing, the damage does not provide evidence as to the nature or the severity of the arc. Figure 14 shows an example of a bead and notch that formed in a 12-2 NM-B conductor that had an over-current trip in Experiment 2.

Examination of the cord/cable photographs did not yield any trend with respect to whether beads/notches/broken strands were present in circuits that tripped as a result of an over-current or with a ground fault. Additionally, there were no trends with respect to cord/cable type and visual damage. Consider the following post exposure magnified photograph of 16-3 SJTW stranded cord from Experiments 1 and 4 (Fig. 15). In Fig. 15, the SJTW cord from Experiment 1 had several broken strands with some beading. In the case of Experiment 4, the SJTW connected to a GFCI, there were no noticeable broken strands but beading was present. Beading and broken strands were not unique to any particular circuit protection. In cases where all strands had broken, the sample was identified to be broken. For an overview of the damage to each cord for all of the experiments, see Table 18 in Appendix 5. While some broken strands and larger beads were visible without magnification, the use of a digital microscope provided a more complete assessment of the damage to the cords.

\section{Future Research Needs}

These experiments exposed energized electrical cords/cables to compartment fire conditions. The placement of the cords and cables at the opening of the compartment provided the most severe exposure. As the compartment fire transitioned to flashover the heat flux exposure to the cords on the floor ignited the thermoplastic insulation of 
the cords. An extension of these experiments would be to change the exposure location. Does depth in the room, where the exposure would be less severe have an impact on the electrical response or physical performance of the cables and cords? The second variable is ventilation. Ventilation is known to impact fire patterns [10]. Cord and cable performance as a function of exposure location and ventilation could help inform fire investigators as well as the impact of combustible interior finishes.

These experiments only examined one electrical configuration and the circuit protection devices were remote from the exposure. The configuration was limited in that the high available current and short homerun distance would not be used if the configuration was designed to UL 1699. As a result, conducting experiments to examine consistency of circuit trips with similar thermal exposures but varied electrical configurations could provide valuable information to fire investigation community.

\section{Conclusions}

This set of experiments was conducted to examine the response of energized cords and different types of circuit protection devices to a growing compartment fire. Four cord types (18-2 SPT1, 16-3 SJTW, 18-3 SVT, 18-2 NISPT-2) and two cable types (12-2 NM-B, 12-3 NM-B) as well as three types of circuit protection (MCCB, AFCI, GFCI) were subjected to six room-scale fire exposures. The six room fires consisted of three replicate fires with two sofas as the main fuel components, two replicate fires with one sofa as the main fuel component and one fire with two sofa and vinyl-covered MDF paneling on three walls of the room. Compared to prior work, each of the fuel packages was sufficient to support flashover conditions in the room and as a result, the exposures in these experiments could be characterized as faster and more severe.

All of the circuits faulted in each of the experiments by either an over-current trip or a ground-fault trip. While all three circuit types tripped in every experiment, it cannot be assumed that an arc-fault or ground-fault caused an AFCI or GFCI circuit to trip. The only cord types that tripped with a ground-fault were the non-metallic sheathed (12-2 NM-B and 12-3 NM-B) cables. This was likely due to the presence of a bare grounding conductor. Assessments of both thermal exposure and physical damage did not reveal any correlation between the total integrated heat flux exposure or the type/magnitude of damage (broken strands, beads, notches) and the signal response (trip type).

For the fire investigator, with regard to the thermal exposure prior to the circuit trip, in each case, the heat flux exposure was in excess of $70 \mathrm{~kW} / \mathrm{m}^{2}$ and the insulation was burning prior to the trip. Further no correlation could be found between the post-fire damage on the exposed samples and the type of circuit protection device it was connected to.

\section{Acknowledgements}

This project was supported by Award No. 2015-DN-BX-K052, awarded by the National Institute of Justice, Office of Justice Programs, U.S. Department of Jus- 
tice. The opinions, findings, and conclusions or recommendations expressed in this publication/program/exhibition are those of the author(s) and do not necessarily reflect those of the Department of Justice. To assist in the design and implementation of the experiments for this study, fire service experts with knowledge in fire investigation and burn patterns were gathered from across the United States. The individuals below provided direction for the project by assisting in planning the experiments, witnessing the testing, and developing concrete conclusions. Their tireless support and efforts make this project relevant to the fire safety community across the world. The authors would also like to acknowledge Paul Brazis, Kelly Opert, Robert James, and the technical staff from the large fire lab of UL LLC for their dedication in conducting these full-scale experiments. These experiments would not have been possible without the UL FSRI team. The UL FSRI team instrumented, conducted, and analyzed these experiments. The authors thank: Robin Zevotek, Keith Stakes, Jack Regan, Joshua Crandall, Steve Kerber, Sarah Huffman, and especially Roy McLane of Thermal Fabrications.

\section{Open Access}

This article is distributed under the terms of the Creative Commons Attribution 4.0 International License (http://creativecommons.org/licenses/by/4.0/), which permits unrestricted use, distribution, and reproduction in any medium, provided you give appropriate credit to the original author(s) and the source, provide a link to the Creative Commons license, and indicate if changes were made.

\section{Appendix 1 : Sofa Heat Release Rate}

Heat release rate replicates for the sofas used in the six experiments conducted in this series. All ignitions occurred with an electric matchbook. The sofas burned in the absence of a compartment and quantified using oxygen consumption calorimetry (Fig. 16).

\section{Appendix 2: Available Fault Current}

See Tables 9 and 10 for the available fault current and definitions, respectively.

\section{Table 9}

Available Fault Current Data

\begin{tabular}{lccccccc}
\hline Circuit & $\begin{array}{c}\mathrm{V}_{\text {open }} \\
(\mathrm{V})\end{array}$ & $\begin{array}{c}\mathrm{V}_{\text {low }} \\
(\mathrm{V})\end{array}$ & $\begin{array}{c}\mathrm{A}_{\text {low }} \\
(\mathrm{A})\end{array}$ & $\begin{array}{c}\mathrm{V}_{\text {high }} \\
(\mathrm{V})\end{array}$ & $\begin{array}{c}\mathrm{A}_{\text {high }} \\
(\mathrm{A})\end{array}$ & $\begin{array}{c}\text { Circuit } \\
\text { Impedance }(\Omega)\end{array}$ & $\begin{array}{c}\text { Available } \\
\text { Fault current (A) }\end{array}$ \\
\hline Phase A & 120.57 & 120.36 & 1.1102 & 118.81 & 600.4 & 0.1634 & 738 \\
Phase B & 120.76 & 120.57 & 1.1076 & 119.04 & -453.9 & 0.1606 & 752 \\
Phase C & 120.74 & 120.50 & 1.1099 & 118.95 & 599.7 & 0.1628 & 741 \\
\hline
\end{tabular}




\section{Table 10}

Fault Current Calculation Definitions

\begin{tabular}{ll}
\hline Variable & \multicolumn{1}{c}{ Definition } \\
\hline $\mathrm{V}_{\text {open }}$ & Voltage - open circuit \\
$\mathrm{V}_{\text {low }}$ & Voltage closed circuit, low current Load \\
$\mathrm{A}_{\text {low }}$ & Amperage - low current load \\
$\mathrm{V}_{\text {high }}$ & Voltage - closed circuit, high current Load \\
$\mathrm{A}_{\text {high }}$ & Amperage-high current load \\
Circuit impedance $(\Omega)$ & $\left(\mathrm{V}_{\text {low }}-\mathrm{V}_{\text {high }}\right) /\left(\mathrm{A}_{\text {high }}-\mathrm{A}_{\text {low }}\right)$ \\
Available fault current & $\mathrm{V}_{\text {open }} / \Omega$ \\
\hline
\end{tabular}

\section{Appendix 3: Gain Calculations}

See Table 11 for the gain calculations.

\section{Table 11}

\section{Gain Calculations}

\begin{tabular}{lcrrc}
\hline Circuit \# & $\begin{array}{c}\text { Decade } \\
\text { Setting }(\Omega)\end{array}$ & $\begin{array}{c}\text { Metered } \\
\mathrm{mA}_{\text {RMS }}\end{array}$ & $\begin{array}{c}\text { Metered } \\
\mathrm{mV}_{\text {RMS }}\end{array}$ & $\begin{array}{c}\text { Calculated } \\
\text { Gain }\end{array}$ \\
\hline 1 & 12,010 & 10.0 & 10.73 & 0.932 \\
2 & 12,010 & 10.0 & 10.66 & 0.938 \\
3 & 30,040 & 4.0 & 4.48 & 0.894 \\
4 & 12,010 & 10.0 & 11.06 & 0.904 \\
5 & 12,010 & 10.0 & 9.62 & 1.040 \\
6 & 30,040 & 4.0 & 4.66 & 0.859 \\
7 & 12,010 & 10.0 & 9.41 & 1.063 \\
8 & 12,010 & 10.0 & 10.59 & 0.944 \\
9 & 30,040 & 4.0 & 4.11 & 0.974 \\
10 & 12,010 & 10.0 & 10.35 & 0.966 \\
11 & 12,010 & 10.0 & 10.88 & 0.919 \\
12 & 30,040 & 4.0 & 10.37 & 0.916 \\
13 & 12,010 & 10.0 & 10.95 & 0.935 \\
14 & 12,010 & 10.0 & 4.42 & 0.913 \\
15 & 30,040 & 4.0 & 10.92 & 0.905 \\
16 & 12,010 & 10.0 & 11.06 & 0.916 \\
17 & 12,010 & 4.50 & 0.904 \\
18 & 30,040 & 4.0 & 0.890 \\
\hline
\end{tabular}

\section{Appendix 4: Fault Data}

See Tables 12, 13, 14, 15, 16 and 17 for the trip data for each of the six experiments conducted. This data includes time to trip, integrated heat flux at time of time, the current and differential current at the time of trip, and the trip type for each exposed circuit. 
Table 12

Circuit Trip Data for Experiment 1

\begin{tabular}{|c|c|c|c|c|c|c|c|}
\hline $\begin{array}{l}\text { Circuit } \\
\text { \# }\end{array}$ & $\begin{array}{l}\text { Breaker } \\
\text { type }\end{array}$ & $\begin{array}{l}\text { Cord/cable } \\
\text { type }\end{array}$ & $\begin{array}{l}\text { Time } \\
(\mathrm{s})\end{array}$ & $\begin{array}{l}\text { Integrated heat flux } \\
\qquad\left(\mathrm{MJ} / \mathrm{m}^{2}\right)\end{array}$ & $\begin{array}{l}\text { Current } \\
\text { (A) }\end{array}$ & $\begin{array}{l}\text { Diff. Curr. } \\
\text { (mA) }\end{array}$ & Trip type \\
\hline 1 & MCCB & 18-2 SPT1 & 268.9 & 19.2 & 600.4 & -71.7 & $\begin{array}{l}\text { Over-Cur- } \\
\text { rent }\end{array}$ \\
\hline 2 & AFCI & 18-2 SPT1 & 267.2 & 18.0 & -453.9 & -6.8 & $\begin{array}{l}\text { Over-Cur- } \\
\text { rent }\end{array}$ \\
\hline 3 & GFCI & 18-2 SPT1 & 268.1 & 18.9 & 599.7 & 3.3 & $\begin{array}{l}\text { Over-Cur- } \\
\text { rent }\end{array}$ \\
\hline 4 & MCCB & 16-3 SJTW & 313.8 & 60.0 & 687.6 & 95.5 & $\begin{array}{l}\text { Over-Cur- } \\
\text { rent }\end{array}$ \\
\hline 5 & AFCI & 16-3 SJTW & 299.5 & 47.8 & 643.8 & 109.8 & $\begin{array}{l}\text { Over-Cur- } \\
\text { rent }\end{array}$ \\
\hline 6 & GFCI & 16-3 SJTW & 304.3 & 52.6 & 591.4 & 90.7 & $\begin{array}{l}\text { Over-Cur- } \\
\text { rent }\end{array}$ \\
\hline 7 & MCCB & $12-2$ NM-B & 298.0 & 30.6 & 585.6 & 112.2 & $\begin{array}{l}\text { Over-Cur- } \\
\text { rent }\end{array}$ \\
\hline 8 & AFCI & $12-2$ NM-B & 300.2 & 31.7 & 31.7 & 79.4 & $\begin{array}{l}\text { Ground } \\
\text { Fault }\end{array}$ \\
\hline 9 & GFCI & 12-2 NM-B & 286.1 & 34.5 & -6.6 & 8.1 & $\begin{array}{l}\text { Ground } \\
\text { Fault }\end{array}$ \\
\hline 10 & $\mathrm{MCCB}$ & $12-3$ NM-B & 304.0 & 52.3 & -585.2 & 102.0 & $\begin{array}{l}\text { Over-Cur- } \\
\text { rent }\end{array}$ \\
\hline 11 & AFCI & $12-3 \mathrm{NM}-\mathrm{B}$ & 305.0 & 50.6 & 687.6 & -68.7 & $\begin{array}{l}\text { Over-Cur- } \\
\text { rent }\end{array}$ \\
\hline 12 & GFCI & 12-3 NM-B & 283.5 & 30.4 & -3.1 & 8.2 & $\begin{array}{l}\text { Ground } \\
\text { Fault }\end{array}$ \\
\hline 13 & MCCB & 18-3 SVT & 283.3 & 29.3 & 447.4 & -98.4 & $\begin{array}{l}\text { Over-Cur- } \\
\text { rent }\end{array}$ \\
\hline 14 & AFCI & 18-3 SVT & 288.1 & 33.2 & 460.3 & 96.4 & $\begin{array}{l}\text { Over-Cur- } \\
\text { rent }\end{array}$ \\
\hline 15 & GFCI & 18-3 SVT & 283.0 & 26.7 & 573.3 & -11.2 & $\begin{array}{l}\text { Over-Cur- } \\
\text { rent }\end{array}$ \\
\hline 16 & MCCB & $\begin{array}{l}18-2 \\
\text { NISPT-2 }\end{array}$ & 289.1 & 31.7 & 503.5 & -4.6 & $\begin{array}{l}\text { Over-Cur- } \\
\text { rent }\end{array}$ \\
\hline 17 & AFCI & $\begin{array}{l}18-2 \\
\text { NISPT-2 }\end{array}$ & 283.4 & 24.1 & -515.4 & 11.0 & $\begin{array}{l}\text { Over-Cur- } \\
\text { rent }\end{array}$ \\
\hline 18 & GFCI & $\begin{array}{l}18-2 \\
\text { NISPT-2 }\end{array}$ & 288.4 & 27.4 & 503.5 & -7.4 & $\begin{array}{l}\text { Over-Cur- } \\
\text { rent }\end{array}$ \\
\hline
\end{tabular}


Table 13

Circuit Trip Data for Experiment 2

\begin{tabular}{|c|c|c|c|c|c|c|c|}
\hline $\begin{array}{l}\text { Circuit } \\
\text { \# }\end{array}$ & $\begin{array}{l}\text { Breaker } \\
\text { type }\end{array}$ & $\begin{array}{l}\text { Cord/cable } \\
\text { type }\end{array}$ & $\begin{array}{l}\text { Time } \\
(\mathrm{s})\end{array}$ & $\begin{array}{l}\text { Integrated heat flux } \\
\qquad\left(\mathrm{MJ} / \mathrm{m}^{2}\right)\end{array}$ & $\begin{array}{l}\text { Current } \\
\text { (A) }\end{array}$ & $\begin{array}{l}\text { Diff. Curr. } \\
\quad(\mathrm{mA})\end{array}$ & Trip type \\
\hline 1 & MCCB & 18-2 SPT1 & 209.9 & 23.9 & 623.2 & -98.1 & $\begin{array}{l}\text { Over-Cur- } \\
\text { rent }\end{array}$ \\
\hline 2 & AFCI & 18-2 SPT1 & 204.6 & 19.8 & 540.8 & -19.3 & $\begin{array}{l}\text { Over-Cur- } \\
\text { rent }\end{array}$ \\
\hline 3 & GFCI & 18-2 SPT1 & 205.5 & 16.6 & -392.0 & 10.0 & $\begin{array}{l}\text { Over-Cur- } \\
\text { rent }\end{array}$ \\
\hline 4 & MCCB & 16-3 SJTW & 233.8 & 33.0 & -533.1 & 95.5 & $\begin{array}{l}\text { Over-Cur- } \\
\text { rent }\end{array}$ \\
\hline 5 & AFCI & 16-3 SJTW & 235.9 & 44.5 & 578.5 & 109.8 & $\begin{array}{l}\text { Over-Cur- } \\
\text { rent }\end{array}$ \\
\hline 6 & GFCI & 16-3 SJTW & 227.9 & 37.3 & 549.5 & -90.4 & $\begin{array}{l}\text { Over-Cur- } \\
\text { rent }\end{array}$ \\
\hline 7 & $\mathrm{MCCB}$ & $12-2$ NM-B & 230.3 & 30.4 & -625.2 & 112.2 & $\begin{array}{l}\text { Over-Cur- } \\
\text { rent }\end{array}$ \\
\hline 8 & AFCI & $12-2$ NM-B & 223.5 & 26.6 & -2.4 & -73.0 & $\begin{array}{l}\text { Ground } \\
\text { Fault }\end{array}$ \\
\hline 9 & GFCI & 12-2 NM-B & 217.1 & 33.5 & -1.4 & 8.0 & $\begin{array}{l}\text { Ground } \\
\text { Fault }\end{array}$ \\
\hline 10 & MCCB & 12-3 NM-B & 226.5 & 42.2 & -580.7 & 102.0 & $\begin{array}{l}\text { Over-Cur- } \\
\text { rent }\end{array}$ \\
\hline 11 & AFCI & $12-3$ NM-B & 225.8 & 24.5 & -2.4 & -72.6 & $\begin{array}{l}\text { Ground } \\
\text { Fault }\end{array}$ \\
\hline 12 & GFCI & 12-3 NM-B & 211.6 & 17.6 & 1.8 & -8.1 & $\begin{array}{l}\text { Ground } \\
\text { Fault }\end{array}$ \\
\hline 13 & MCCB & 18-3 SVT & 217.7 & 19.8 & -541.1 & 98.7 & $\begin{array}{l}\text { Over-Cur- } \\
\text { rent }\end{array}$ \\
\hline 14 & AFCI & 18-3 SVT & 219.8 & 20.8 & -588.1 & 96.4 & $\begin{array}{l}\text { Over-Cur- } \\
\text { rent }\end{array}$ \\
\hline 15 & GFCI & 18-3 SVT & 216.5 & 23.1 & -547.6 & -24.3 & $\begin{array}{l}\text { Over-Cur- } \\
\text { rent }\end{array}$ \\
\hline 16 & MCCB & $\begin{array}{l}18-2 \\
\text { NISPT-2 }\end{array}$ & 220.6 & 25.4 & 464.2 & 4.1 & $\begin{array}{l}\text { Over-Cur- } \\
\text { rent }\end{array}$ \\
\hline 17 & AFCI & $\begin{array}{l}18-2 \\
\text { NISPT-2 }\end{array}$ & 224.9 & 25.3 & 437.4 & -2.0 & $\begin{array}{l}\text { Over-Cur- } \\
\text { rent }\end{array}$ \\
\hline 18 & GFCI & $\begin{array}{l}18-2 \\
\text { NISPT-2 }\end{array}$ & 221.8 & 23.8 & -553.7 & -13.2 & $\begin{array}{l}\text { Over-Cur- } \\
\text { rent }\end{array}$ \\
\hline
\end{tabular}


Table 14

Circuit Trip Data for Experiment 3

\begin{tabular}{|c|c|c|c|c|c|c|c|}
\hline $\begin{array}{l}\text { Circuit } \\
\text { \# }\end{array}$ & $\begin{array}{l}\text { Breaker } \\
\text { type }\end{array}$ & $\begin{array}{l}\text { Cord/cable } \\
\text { type }\end{array}$ & $\begin{array}{l}\text { Time } \\
(\mathrm{s})\end{array}$ & $\begin{array}{l}\text { Integrated heat flux } \\
\qquad\left(\mathrm{MJ} / \mathrm{m}^{2}\right)\end{array}$ & $\begin{array}{l}\text { Current } \\
\text { (A) }\end{array}$ & $\begin{array}{l}\text { Diff. Curr. } \\
\quad(\mathrm{mA})\end{array}$ & Trip type \\
\hline 1 & MCCB & 18-2 SPT1 & 207.3 & 21.2 & 549.5 & 98.4 & $\begin{array}{l}\text { Over-Cur- } \\
\text { rent }\end{array}$ \\
\hline 2 & AFCI & 18-2 SPT1 & 202.0 & 17.2 & 541.1 & -14.7 & $\begin{array}{l}\text { Over-Cur- } \\
\text { rent }\end{array}$ \\
\hline 3 & GFCI & 18-2 SPT1 & 217.0 & 30.4 & -472.5 & 5.1 & $\begin{array}{l}\text { Over-Cur- } \\
\text { rent }\end{array}$ \\
\hline 4 & MCCB & 16-3 SJTW & 235.6 & 45.9 & -669.0 & 95.5 & $\begin{array}{l}\text { Over-Cur- } \\
\text { rent }\end{array}$ \\
\hline 5 & AFCI & 16-3 SJTW & 228.6 & 41.3 & 443.6 & -109.5 & $\begin{array}{l}\text { Over-Cur- } \\
\text { rent }\end{array}$ \\
\hline 6 & GFCI & 16-3 SJTW & 233.7 & 45.6 & 579.4 & 90.7 & $\begin{array}{l}\text { Over-Cur- } \\
\text { rent }\end{array}$ \\
\hline 7 & $\mathrm{MCCB}$ & $12-2$ NM-B & 227.2 & 40.1 & -461.3 & 112.2 & $\begin{array}{l}\text { Over-Cur- } \\
\text { rent }\end{array}$ \\
\hline 8 & AFCI & $12-2$ NM-B & 235.0 & 46.8 & -2.1 & -76.0 & $\begin{array}{l}\text { Ground } \\
\text { Fault }\end{array}$ \\
\hline 9 & GFCI & 12-2 NM-B & 212.1 & 28.4 & -1.8 & -7.9 & $\begin{array}{l}\text { Ground } \\
\text { Fault }\end{array}$ \\
\hline 10 & MCCB & 12-3 NM-B & 216.9 & 32.6 & 539.5 & 102.0 & $\begin{array}{l}\text { Over-Cur- } \\
\text { rent }\end{array}$ \\
\hline 11 & AFCI & $12-3$ NM-B & 218.5 & 34.1 & -3.7 & -71.6 & $\begin{array}{l}\text { Ground } \\
\text { Fault }\end{array}$ \\
\hline 12 & GFCI & 12-3 NM-B & 215.0 & 31.0 & -2.7 & -7.9 & $\begin{array}{l}\text { Ground } \\
\text { Fault }\end{array}$ \\
\hline 13 & MCCB & 18-3 SVT & 214.5 & 29.5 & -419.1 & 2.0 & $\begin{array}{l}\text { Over-Cur- } \\
\text { rent }\end{array}$ \\
\hline 14 & AFCI & 18-3 SVT & 218.3 & 33.0 & -574.6 & 96.4 & $\begin{array}{l}\text { Over-Cur- } \\
\text { rent }\end{array}$ \\
\hline 15 & GFCI & 18-3 SVT & 218.1 & 28.8 & 570.8 & -94.2 & $\begin{array}{l}\text { Over-Cur- } \\
\text { rent }\end{array}$ \\
\hline 16 & MCCB & $\begin{array}{l}18-2 \\
\text { NISPT-2 }\end{array}$ & 229.3 & 37.4 & 347.3 & 5.0 & $\begin{array}{l}\text { Over-Cur- } \\
\text { rent }\end{array}$ \\
\hline 17 & AFCI & $\begin{array}{l}18-2 \\
\text { NISPT-2 }\end{array}$ & 219.1 & 31.0 & 494.1 & -3.2 & $\begin{array}{l}\text { Over-Cur- } \\
\text { rent }\end{array}$ \\
\hline 18 & GFCI & $\begin{array}{l}18-2 \\
\text { NISPT-2 }\end{array}$ & 224.6 & 36.1 & -422.9 & 13.3 & $\begin{array}{l}\text { Over-Cur- } \\
\text { rent }\end{array}$ \\
\hline
\end{tabular}


Table 15

Circuit Trip Data for Experiment 4

\begin{tabular}{|c|c|c|c|c|c|c|c|}
\hline $\begin{array}{l}\text { Circuit } \\
\#\end{array}$ & $\begin{array}{l}\text { Breaker } \\
\text { type }\end{array}$ & $\begin{array}{l}\text { Cord/cable } \\
\text { type }\end{array}$ & $\begin{array}{l}\text { Time } \\
\text { (s) }\end{array}$ & $\begin{array}{l}\text { Integrated heat flux } \\
\qquad\left(\mathrm{MJ} / \mathrm{m}^{2}\right)\end{array}$ & $\begin{array}{l}\text { Current } \\
\text { (A) }\end{array}$ & $\begin{array}{l}\text { Diff. Curr. } \\
\text { (mA) }\end{array}$ & Trip type \\
\hline 1 & MCCB & 18-2 SPT1 & 217.3 & 28.2 & 558.5 & -98.1 & $\begin{array}{l}\text { Over-Cur- } \\
\text { rent }\end{array}$ \\
\hline 2 & AFCI & 18-2 SPT1 & 209.5 & 21.7 & 503.8 & -19.9 & $\begin{array}{l}\text { Over-Cur- } \\
\text { rent }\end{array}$ \\
\hline 3 & GFCI & 18-2 SPT1 & 211.2 & 24.6 & 418.4 & -13.5 & $\begin{array}{l}\text { Over-Cur- } \\
\text { rent }\end{array}$ \\
\hline 4 & MCCB & 16-3 SJTW & 233.8 & 42.9 & -370.5 & 95.5 & $\begin{array}{l}\text { Over-Cur- } \\
\text { rent }\end{array}$ \\
\hline 5 & AFCI & 16-3 SJTW & 234.6 & 50.6 & -695.0 & 109.8 & $\begin{array}{l}\text { Over-Cur- } \\
\text { rent }\end{array}$ \\
\hline 6 & GFCI & 16-3 SJTW & 235.1 & 51.1 & 545.3 & 90.7 & $\begin{array}{l}\text { Over-Cur- } \\
\text { rent }\end{array}$ \\
\hline 7 & MCCB & $12-2$ NM-B & 227.5 & 38.6 & 603.9 & 112.2 & $\begin{array}{l}\text { Over-Cur- } \\
\text { rent }\end{array}$ \\
\hline 8 & AFCI & $12-2$ NM-B & 225.8 & 37.1 & -20.8 & -76.2 & $\begin{array}{l}\text { Ground } \\
\text { Fault }\end{array}$ \\
\hline 9 & GFCI & 12-2 NM-B & 218.3 & 33.6 & -6.0 & -7.6 & $\begin{array}{l}\text { Ground } \\
\text { Fault }\end{array}$ \\
\hline 10 & $\mathrm{MCCB}$ & 12-3 NM-B & 223.7 & 38.6 & -563.0 & 102.0 & $\begin{array}{l}\text { Over-Cur- } \\
\text { rent }\end{array}$ \\
\hline 11 & AFCI & 12-3 NM-B & 227.0 & 39.7 & 570.8 & 97.0 & $\begin{array}{l}\text { Over-Cur- } \\
\text { rent }\end{array}$ \\
\hline 12 & GFCI & 12-3 NM-B & 218.1 & 32.2 & -6.9 & -8.0 & $\begin{array}{l}\text { Ground } \\
\text { Fault }\end{array}$ \\
\hline 13 & MCCB & 18-3 SVT & 214.3 & 30.0 & 649.0 & -5.7 & $\begin{array}{l}\text { Over-Cur- } \\
\text { rent }\end{array}$ \\
\hline 14 & AFCI & 18-3 SVT & 216.3 & 31.8 & -457.4 & 96.4 & $\begin{array}{l}\text { Over-Cur- } \\
\text { rent }\end{array}$ \\
\hline 15 & GFCI & 18-3 SVT & 214.9 & 25.9 & 388.8 & -95.2 & $\begin{array}{l}\text { Over-Cur- } \\
\text { rent }\end{array}$ \\
\hline 16 & MCCB & $\begin{array}{l}18-2 \\
\text { NISPT-2 }\end{array}$ & 218.1 & 28.3 & -406.8 & -13.6 & $\begin{array}{l}\text { Over-Cur- } \\
\text { rent }\end{array}$ \\
\hline 17 & AFCI & $\begin{array}{l}18-2 \\
\text { NISPT-2 }\end{array}$ & 218.5 & 33.9 & 572.0 & -3.9 & $\begin{array}{l}\text { Over-Cur- } \\
\text { rent }\end{array}$ \\
\hline 18 & GFCI & $\begin{array}{l}18-2 \\
\text { NISPT-2 }\end{array}$ & 218.3 & 33.6 & -480.6 & 19.2 & $\begin{array}{l}\text { Over-Cur- } \\
\text { rent }\end{array}$ \\
\hline
\end{tabular}


Table 16

Circuit Trip Data for Experiment 5

\begin{tabular}{|c|c|c|c|c|c|c|c|}
\hline $\begin{array}{l}\text { Circuit } \\
\#\end{array}$ & $\begin{array}{l}\text { Breaker } \\
\text { Type }\end{array}$ & $\begin{array}{l}\text { Cord/cable } \\
\text { type }\end{array}$ & $\begin{array}{l}\text { Time } \\
(\mathrm{s})\end{array}$ & $\begin{array}{l}\text { Integrated heat flux } \\
\qquad\left(\mathrm{MJ} / \mathrm{m}^{2}\right)\end{array}$ & $\begin{array}{l}\text { Current } \\
\text { (A) }\end{array}$ & $\begin{array}{l}\text { Diff. Curr. } \\
\text { (mA) }\end{array}$ & Trip type \\
\hline 1 & MCCB & 18-2 SPT1 & 237.4 & 24.7 & -637.4 & -98.1 & $\begin{array}{l}\text { Over- } \\
\text { Current }\end{array}$ \\
\hline 2 & AFCI & 18-2 SPT1 & 242.0 & 29.0 & -649.3 & -98.7 & $\begin{array}{l}\text { Over- } \\
\text { Current }\end{array}$ \\
\hline 3 & GFCI & 18-2 SPT1 & 237.9 & 24.5 & -514.4 & -6.7 & $\begin{array}{l}\text { Over- } \\
\text { Current }\end{array}$ \\
\hline 4 & MCCB & 16-3 SJTW & 261.5 & 41.4 & 578.5 & 95.5 & $\begin{array}{l}\text { Over- } \\
\text { Current }\end{array}$ \\
\hline 5 & AFCI & 16-3 SJTW & 255.6 & 45.2 & -661.2 & 109.8 & $\begin{array}{l}\text { Over- } \\
\text { Current }\end{array}$ \\
\hline 6 & GFCI & 16-3 SJTW & 266.8 & 55.1 & -531.1 & 90.7 & $\begin{array}{l}\text { Over- } \\
\text { Current }\end{array}$ \\
\hline 7 & MCCB & 12-2 NM-B & 254.6 & 39.1 & -644.8 & 112.2 & $\begin{array}{l}\text { Over- } \\
\text { Current }\end{array}$ \\
\hline 8 & AFCI & $12-2$ NM-B & 253.0 & 37.9 & 546.0 & 99.7 & $\begin{array}{l}\text { Over- } \\
\text { Current }\end{array}$ \\
\hline 9 & GFCI & 12-2 NM-B & 245.7 & 35.1 & -8.5 & -7.5 & $\begin{array}{l}\text { Ground } \\
\text { Fault }\end{array}$ \\
\hline 10 & $\mathrm{MCCB}$ & $12-3$ NM-B & 260.2 & 46.0 & 659.9 & 102.0 & $\begin{array}{l}\text { Over- } \\
\text { Current }\end{array}$ \\
\hline 11 & AFCI & 12-3 NM-B & 248.1 & 36.5 & 1.8 & -68.8 & $\begin{array}{l}\text { Ground } \\
\text { Fault }\end{array}$ \\
\hline 12 & GFCI & 12-3 NM-B & 240.9 & 30.3 & -26.6 & -7.8 & $\begin{array}{l}\text { Ground } \\
\text { Fault }\end{array}$ \\
\hline 13 & MCCB & 18-3 SVT & 239.5 & 29.6 & 518.3 & -2.2 & $\begin{array}{l}\text { Over- } \\
\text { Current }\end{array}$ \\
\hline 14 & AFCI & 18-3 SVT & 240.7 & 30.8 & 563.3 & -96.4 & $\begin{array}{l}\text { Over- } \\
\text { Current }\end{array}$ \\
\hline 15 & GFCI & 18-3 SVT & 241.0 & 29.4 & -503.4 & -23.5 & $\begin{array}{l}\text { Over- } \\
\text { Current }\end{array}$ \\
\hline 16 & МCCB & $\begin{array}{l}18-2 \\
\text { NISPT-2 }\end{array}$ & 244.5 & 32.5 & 443.6 & 4.4 & $\begin{array}{l}\text { Over- } \\
\text { Current }\end{array}$ \\
\hline 17 & AFCI & $\begin{array}{l}18-2 \\
\text { NISPT-2 }\end{array}$ & 243.6 & 29.3 & -541.4 & -9.1 & $\begin{array}{l}\text { Over- } \\
\text { Current }\end{array}$ \\
\hline 18 & GFCI & $\begin{array}{l}18-2 \\
\text { NISPT-2 }\end{array}$ & 243.1 & 29.1 & 444.5 & -13.9 & $\begin{array}{l}\text { Over- } \\
\text { Current }\end{array}$ \\
\hline
\end{tabular}


Table 17

Circuit Trip Data for Experiment 6

\begin{tabular}{|c|c|c|c|c|c|c|c|}
\hline $\begin{array}{l}\text { Circuit } \\
\#\end{array}$ & $\begin{array}{l}\text { Breaker } \\
\text { type }\end{array}$ & $\begin{array}{l}\text { Cord/cable } \\
\text { type }\end{array}$ & $\begin{array}{l}\text { Time } \\
\text { (s) }\end{array}$ & $\begin{array}{l}\text { Integrated heat flux } \\
\qquad\left(\mathrm{MJ} / \mathrm{m}^{2}\right)\end{array}$ & $\begin{array}{l}\text { Current } \\
\text { (A) }\end{array}$ & $\begin{array}{l}\text { Diff. Curr. } \\
\text { (mA) }\end{array}$ & Trip type \\
\hline 1 & МCCB & 18-2 SPT1 & 205.5 & 18.2 & 466.4 & -98.1 & $\begin{array}{l}\text { Over-Cur- } \\
\text { rent }\end{array}$ \\
\hline 2 & AFCI & 18-2 SPT1 & 210.5 & 21.9 & -550.5 & -8.8 & $\begin{array}{l}\text { Over-Cur- } \\
\text { rent }\end{array}$ \\
\hline 3 & GFCI & 18-2 SPT1 & 223.0 & 32.1 & 521.5 & -17.9 & $\begin{array}{l}\text { Over-Cur- } \\
\text { rent }\end{array}$ \\
\hline 4 & MCCB & 16-3 SJTW & 240.6 & 49.4 & -540.5 & -95.1 & $\begin{array}{l}\text { Over-Cur- } \\
\text { rent }\end{array}$ \\
\hline 5 & AFCI & 16-3 SJTW & 244.7 & 74.0 & 655.1 & 109.8 & $\begin{array}{l}\text { Over-Cur- } \\
\text { rent }\end{array}$ \\
\hline 6 & GFCI & 16-3 SJTW & 236.1 & 61.9 & -566.2 & 90.7 & $\begin{array}{l}\text { Over-Cur- } \\
\text { rent }\end{array}$ \\
\hline 7 & MCCB & $12-2$ NM-B & 228.2 & 40.8 & 543.4 & 112.2 & $\begin{array}{l}\text { Over-Cur- } \\
\text { rent }\end{array}$ \\
\hline 8 & AFCI & $12-2$ NM-B & 223.0 & 35.3 & -2.1 & -86.9 & $\begin{array}{l}\text { Ground } \\
\text { Fault }\end{array}$ \\
\hline 9 & GFCI & 12-2 NM-B & 223.0 & 36.4 & -2.7 & -7.9 & $\begin{array}{l}\text { Ground } \\
\text { Fault }\end{array}$ \\
\hline 10 & $\mathrm{MCCB}$ & 12-3 NM-B & 231.7 & 46.5 & -539.8 & 102.0 & $\begin{array}{l}\text { Over-Cur- } \\
\text { rent }\end{array}$ \\
\hline 11 & AFCI & $12-3$ NM-B & 226.5 & 35.4 & 11.4 & -69.9 & $\begin{array}{l}\text { Ground } \\
\text { Fault }\end{array}$ \\
\hline 12 & GFCI & 12-3 NM-B & 216.6 & 25.9 & -2.1 & -7.8 & $\begin{array}{l}\text { Ground } \\
\text { Fault }\end{array}$ \\
\hline 13 & MCCB & 18-3 SVT & 218.8 & 30.2 & -519.5 & 98.7 & $\begin{array}{l}\text { Over-Cur- } \\
\text { rent }\end{array}$ \\
\hline 14 & AFCI & 18-3 SVT & 219.6 & 31.0 & -513.1 & 96.4 & $\begin{array}{l}\text { Over-Cur- } \\
\text { rent }\end{array}$ \\
\hline 15 & GFCI & 18-3 SVT & 217.7 & 29.1 & -621.0 & -26.3 & $\begin{array}{l}\text { Over-Cur- } \\
\text { rent }\end{array}$ \\
\hline 16 & MCCB & $\begin{array}{l}18-2 \\
\text { NISPT-2 }\end{array}$ & 218.8 & 30.2 & -427.1 & -9.6 & $\begin{array}{l}\text { Over-Cur- } \\
\text { rent }\end{array}$ \\
\hline 17 & AFCI & $\begin{array}{l}18-2 \\
\text { NISPT-2 }\end{array}$ & 226.6 & 38.6 & 460.6 & -7.4 & $\begin{array}{l}\text { Over-Cur- } \\
\text { rent }\end{array}$ \\
\hline 18 & GFCI & $\begin{array}{l}18-2 \\
\text { NISPT-2 }\end{array}$ & 223.7 & 34.7 & 446.1 & -8.5 & $\begin{array}{l}\text { Over-Cur- } \\
\text { rent }\end{array}$ \\
\hline
\end{tabular}

\section{Appendix 5: Physical Cord/Cable Damage}

See Table 18 for physical observations of each circuit, for each of the six experiments. 
Table 18

Post Experiment Physical Observations on Cords

\begin{tabular}{|c|c|c|c|c|c|c|c|c|}
\hline \multirow{2}{*}{$\begin{array}{l}\text { Circuit } \\
\#\end{array}$} & \multirow{2}{*}{$\begin{array}{l}\text { Breaker } \\
\text { Type }\end{array}$} & \multirow{2}{*}{$\begin{array}{c}\text { Cord/cable } \\
\text { Type }\end{array}$} & \multicolumn{6}{|c|}{ Physical observations } \\
\hline & & & Exp 1 & Exp 2 & Exp 3 & Exp 4 & Exp 5 & Exp 6 \\
\hline 1 & $\mathrm{MCCB}$ & 18-2 SPT1 & $\begin{array}{l}\text { Broken, } \\
\text { beads }\end{array}$ & Broken & $\begin{array}{l}\text { Broken, } \\
\text { beads }\end{array}$ & Broken & Broken & Broken \\
\hline 2 & AFCI & 18-2 SPT1 & Broken & $\begin{array}{l}\text { Broken } \\
\text { strand, } \\
\text { bead }\end{array}$ & $\begin{array}{l}\text { Broken, } \\
\text { beads }\end{array}$ & Broken & Bead & Broken \\
\hline 3 & GFCI & 18-2 SPT1 & Broken & Broken & $\begin{array}{l}\text { Broken, } \\
\text { beads }\end{array}$ & $\begin{array}{l}\text { Broken } \\
\text { strands }\end{array}$ & Broken & Broken \\
\hline 4 & $\mathrm{MCCB}$ & $\begin{array}{l}16-3 \\
\text { SJTW }\end{array}$ & $\begin{array}{l}\text { Broken } \\
\text { strand, } \\
\text { beading }\end{array}$ & $\begin{array}{l}\text { Broken } \\
\text { strand, } \\
\text { beads }\end{array}$ & $\begin{array}{l}\text { Broken } \\
\text { strand, } \\
\text { notch }\end{array}$ & - & $\begin{array}{l}\text { Broken } \\
\text { strands, } \\
\text { beads }\end{array}$ & $\begin{array}{l}\text { Broken } \\
\text { strands }\end{array}$ \\
\hline 5 & AFCI & $\begin{array}{l}16-3 \\
\text { SJTW }\end{array}$ & - & Bead & $\begin{array}{l}\text { Broken } \\
\text { strand }\end{array}$ & $\begin{array}{l}\text { Broken } \\
\text { strands }\end{array}$ & - & $\begin{array}{l}\text { Notch, } \\
\text { bead }\end{array}$ \\
\hline 6 & GFCI & $\begin{array}{l}16-3 \\
\text { SJTW }\end{array}$ & - & $\begin{array}{l}\text { Broken } \\
\text { strand, } \\
\text { bead }\end{array}$ & Bead & $\begin{array}{l}\text { Broken } \\
\text { strand, } \\
\text { bead }\end{array}$ & - & $\begin{array}{l}\text { Broken } \\
\text { strand }\end{array}$ \\
\hline 7 & $\mathrm{MCCB}$ & $\begin{array}{l}12-2 \text { NM- } \\
B\end{array}$ & $\begin{array}{l}\text { Notch, } \\
\text { bead }\end{array}$ & $\begin{array}{l}\text { Notch, } \\
\text { bead }\end{array}$ & $\begin{array}{l}\text { Notch, } \\
\text { bead }\end{array}$ & $\begin{array}{l}\text { Notch, } \\
\text { beads }\end{array}$ & $\begin{array}{l}\text { Notch, } \\
\text { beads }\end{array}$ & $\begin{array}{l}\text { Notch, } \\
\text { bead }\end{array}$ \\
\hline 8 & AFCI & $\begin{array}{l}12-2 \text { NM- } \\
\text { B }\end{array}$ & - & - & - & - & $\begin{array}{l}\text { Notch, } \\
\text { bead }\end{array}$ & Notch \\
\hline 9 & GFCI & $\begin{array}{l}\text { 12-2 NM- } \\
\text { B }\end{array}$ & - & - & - & Notch & - & - \\
\hline 10 & $\mathrm{MCCB}$ & $\begin{array}{l}\text { 12-3 NM- } \\
\text { B }\end{array}$ & - & $\begin{array}{l}\text { Notch, } \\
\text { bead }\end{array}$ & - & $\begin{array}{l}\text { Notch, } \\
\text { bead }\end{array}$ & $\begin{array}{l}\text { Notch, } \\
\text { beads }\end{array}$ & - \\
\hline 11 & AFCI & $\begin{array}{l}12-3 \text { NM- } \\
\text { B }\end{array}$ & - & - & - & Notches & $\begin{array}{l}\text { Small } \\
\text { beads }\end{array}$ & - \\
\hline 12 & GFCI & $\begin{array}{l}\text { 12-3 NM- } \\
\text { B }\end{array}$ & - & - & - & - & - & Bead \\
\hline 13 & $\mathrm{MCCB}$ & 18-3 SVT & - & $\begin{array}{l}\text { Notch, } \\
\text { bead }\end{array}$ & $\begin{array}{l}\text { Broken } \\
\text { strands, } \\
\text { beads }\end{array}$ & $\begin{array}{l}\text { Broken } \\
\text { strands, } \\
\text { beads }\end{array}$ & $\begin{array}{l}\text { Broken } \\
\text { strands }\end{array}$ & $\begin{array}{l}\text { Broken } \\
\text { strands }\end{array}$ \\
\hline 14 & AFCI & 18-3 SVT & $\begin{array}{l}\text { Broken } \\
\text { strand }\end{array}$ & $\begin{array}{l}\text { Notch, } \\
\text { bead }\end{array}$ & $\begin{array}{l}\text { Broken } \\
\text { strands }\end{array}$ & $\begin{array}{l}\text { Broken } \\
\text { strands, } \\
\text { bead }\end{array}$ & $\begin{array}{l}\text { Broken } \\
\text { strands }\end{array}$ & $\begin{array}{l}\text { Broken } \\
\text { strands }\end{array}$ \\
\hline 15 & GFCI & 18-3 SVT & $\begin{array}{l}\text { Broken } \\
\text { strand, } \\
\text { beading }\end{array}$ & Bead & $\begin{array}{l}\text { Broken } \\
\text { strands }\end{array}$ & $\begin{array}{l}\text { Broken } \\
\text { strands }\end{array}$ & Bead & $\begin{array}{l}\text { Broken } \\
\text { strands }\end{array}$ \\
\hline 16 & MCCB & $\begin{array}{l}18-2 \\
\text { NISPT-2 }\end{array}$ & $\begin{array}{l}\text { Broken } \\
\text { strand, } \\
\text { beading }\end{array}$ & - & $\begin{array}{l}\text { Broken } \\
\text { strands }\end{array}$ & $\begin{array}{l}\text { Broken } \\
\text { strands }\end{array}$ & $\begin{array}{l}\text { Broken } \\
\text { strands }\end{array}$ & $\begin{array}{l}\text { Broken } \\
\text { strands }\end{array}$ \\
\hline 17 & AFCI & $\begin{array}{l}18-2 \\
\text { NISPT-2 }\end{array}$ & $\begin{array}{l}\text { Broken } \\
\text { strand, } \\
\text { beading }\end{array}$ & - & $\begin{array}{l}\text { Broken } \\
\text { strands }\end{array}$ & $\begin{array}{l}\text { Broken } \\
\text { strands }\end{array}$ & $\begin{array}{l}\text { Broken } \\
\text { strands }\end{array}$ & $\begin{array}{l}\text { Broken } \\
\text { strands }\end{array}$ \\
\hline 18 & GFCI & $\begin{array}{l}18-2 \\
\text { NISPT-2 }\end{array}$ & $\begin{array}{l}\text { Broken } \\
\text { strand, } \\
\text { beading }\end{array}$ & Bead & $\begin{array}{l}\text { Broken } \\
\text { strands, } \\
\text { beads }\end{array}$ & - & $\begin{array}{l}\text { Broken } \\
\text { strands }\end{array}$ & $\begin{array}{l}\text { Broken } \\
\text { strands }\end{array}$ \\
\hline
\end{tabular}




\section{References}

1. Babrauskas V (2018) Arc mapping: a critical review. Fire Technol 54:749-780. https:// doi.org/10.1007/s10694-018-0711-5

2. Béland B (1980) Examination of electrical conductors following a fire. Fire Technol 16(4):252-258

3. Béland B (1981) Arcing phenomenon as related to fire investigation. Fire Technol 17(3):189-201

4. Béland B (1982) Considerations on arcing as a fire cause. Fire Technol 18(2):188-202

5. Benfer M, Gottuk D (2013) Development and Analysis of Electrical Receptacle Fires. Tech. rep., Report to the United States Department of Justice (Grant\# 243828)

6. Blevins L (1999) Behavior of bare and aspirated thermocouples in compartment fires. In: 33rd proceedings of the national heat transfer conference, pp 15-17

7. Bryant R, Mullholland G (2008) A guide to characterizing heat release rate measurement uncertainty for full-scale fire tests. Fire Mater 32:121-139

8. Hoffman J, Hoffmann DJ, Kroll E, Wallace J, Kroll M (2001) Electrical power cord damage from radiant heat and fire exposure. Fire Technol 34(1):29-42

9. Huggett C (1980) Estimation of rate of heat release by means of oxygen consumption measurements. Fire Mater 4(2):61-65

10. Madrzykowski D, Weinschenk C (2019) Impact of fixed ventilation on fire damage patterns in full-scale structures

11. National Fire Protection Association, Quincy, Massachusetts: NFPA 70, National Electrical Code (2017)

12. National Fire Protection Association, Quincy, Massachusetts: NFPA 921, Guide for Fire and Explosion Investigations (2017)

13. NIJ Forensic Science Technology Working Group (2014) Technology Working Group Operational Requirements. https:/www.nij.gov/topics/forensics/documents/2014-forensi c-twg-table.pdf

14. Novak C (2001) An Analysis of Heat-Flux Induced Arc Formation in a Residential Electrical Cables. Master's Thesis, University of Maryland, College Park, Maryland

15. Novak C, Stoliarov S, Keller M, Quintiere J (2013) An analysis of heat flux induced arc formation in a residential electrical cable. Fire Saf J 55:61-68

16. Peacock RD, Reneke P, Bukowski RW, Babrauskas V (1999) Defining flashover for fire hazard calculations. Fire Saf J 32(4):331-345

17. Pitts W, Braun E, Peacock R, Mitler H, Johnson E, Reneke P, Blevins L (2003) Temperature uncertainties for bare-bead and aspirated thermocouple measurements in fire environments. ASTM Spec Tech Publ 1427:3-15

18. Pitts W, Murthy A, de Ris J, Filtz J, Nygård K, Smith D, Wetterlund I (2006) Round robin study of total heat flux gauge calibration at fire laboratories. Fire Saf $\mathbf{J}$ 41(6):459-475

Publisher's Note Springer Nature remains neutral with regard to jurisdictional claims in published maps and institutional affiliations. 